Davi Noboru Nakano

\title{
Dois Estudos de Caso sobre Centralização e DESCENTRALIZAÇÃO DE ATIVIDADES DE ENGENHARIA
}

\author{
Dissertação apresentada à Escola Politécnica da \\ Universidade de São Paulo para a obtenção do \\ título de Mestre em Engenharia \\ Área de Concentração: \\ Engenharia de Produção \\ Orientador: \\ Afonso Carlos Corrêa Fleury
}

São Paulo 
Nakano, Davi Noboru

Dois estudos de caso sobre centralização e descentralização de atividades de Engenharia. São Paulo, 1997.

80p.

Dissertação (Mestrado) - Escola Politécnica da Universidade de São Paulo. Departamento de Engenharia de Produção.

1. Processo de inovação tecnológica 2. Arranjos organizacionais da Engenharia I. Universidade de São Paulo. Escola Politécnica. Departamento de Engenharia de Produção. II. $t$

DEDALUS - Acervo - EPBC

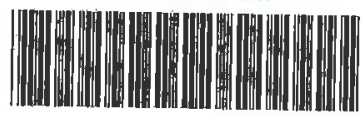

31200030224

$F D-2.28$ 


\section{ERRATA}

\section{Candidato:}

Davi Noboru Nakano

\section{Título do trabalho:}

Dois estudos de caso sobre centralização e descentralização de atividades de Engenharia.

\section{Banca Examinadora:}

Prof. Dr. Afonso Carlos Corrêa Fleury (Orientador)

Prof. Dr. Isak Kruglianskas

Prof. Dr. Francisco Ferreira Cardoso

\section{Correções e comentários:}

1. p.48, $3^{\circ}$. parágrafo, $\mathbf{1}^{\circ}$. linha - O esquema citado é o da figura 13 e não o da figura 14.

2. p.54 - tabela 5 - Não considerar a linha Natureza da comunicação, não faz parte dessa tabela.

3. p.55, $\mathbf{1}^{\circ}$. parágrafo, $\mathbf{1}^{\circ}$. e $\mathbf{3}^{\circ}$. linha - Abreviatura de horas é " $\mathrm{h}$ ", e não "hs".

4. A questão inicial de pesquisa é apresentada de forma ampla. No sentido mais estrito, ela pode ser formulada como: "Quais os condicionantes que determinam o tipo de arranjo organizacional e seu grau de centralização e descentralização em empresas com múltiplos departamentos de Engenharia?"' 


\section{SUMÁRIO}

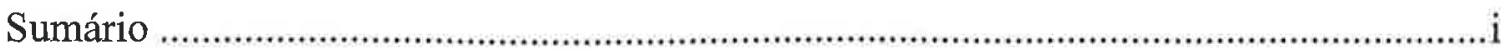

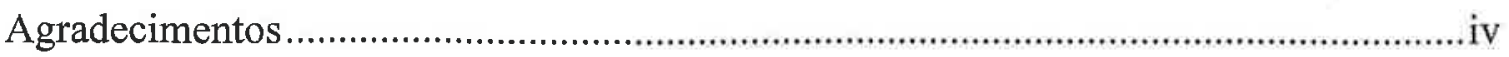

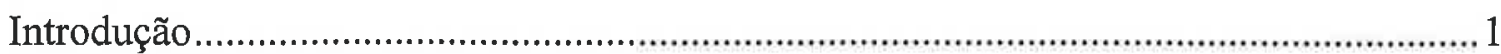

Conceito e Atividades da Engenharia ............................................................................

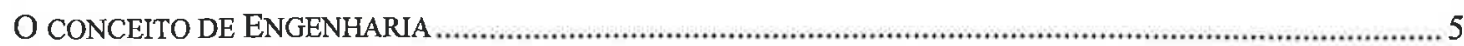

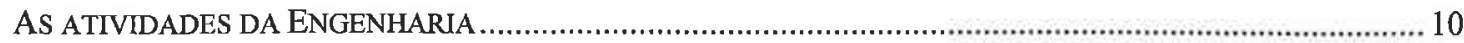

Os arranjos organizacionais da Engenharia......................................................... 15

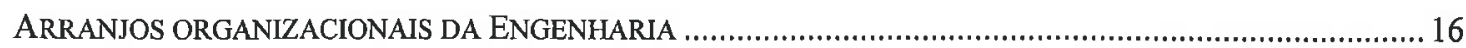

Arranjos internos a uma unidade de Engenharia.............................................................................. 16

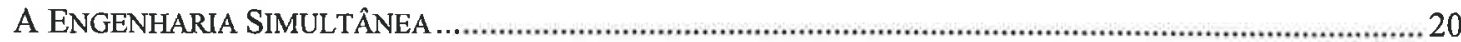

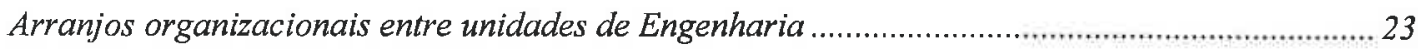

Gestão de empresas multinacionais: alguns conceitos importantes..............................................22

Arranjos Organizacionais e a capacidade de processamento de informações..................30

ARRANJOS ORGANIZACIONAIS DA ENGENHARIA E OS FLUXOS DE INFORMAÇÕES...................................... 30

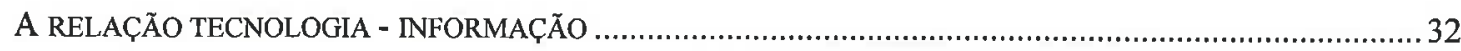

A CAPACIDADE DE PROCESSAMENTO DE INFORMAÇŌES COMO FERRAMENTA DE ESTUDO DE ARRANJOS

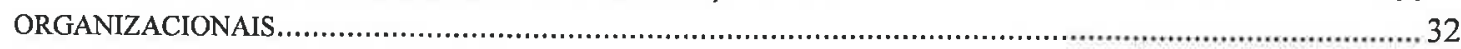

Fatores geradores de necessidade de informações ........................................................................ 34

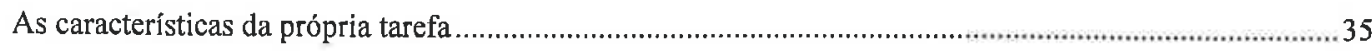

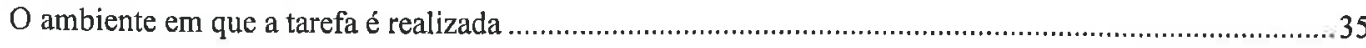

Grau de interdependência entre as diversas unidades dentro da organização...............................................37

Fatores de influência na capacidade de processamento de informações ..........................................39

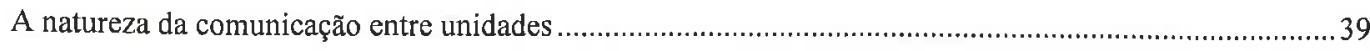

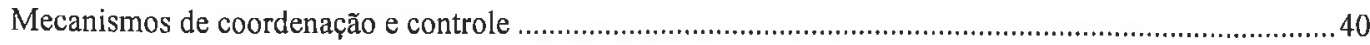

Mecanismos adicionais para aumento da capacidade de processamento de informações............................42

OS ARRANJOS ENTRE UNIDADES DE ENGENHARIA E A CAPACIDADE DE PROCESSAMENTO DE INFORMAÇÕES 
Metodologia e formulação das perguntas de pesquisa ...................................................47

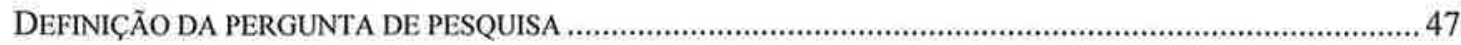

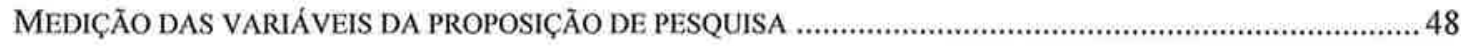

MÉTODO DE PESQUISA A SER EMPREGADO ……………………..................................................... 52

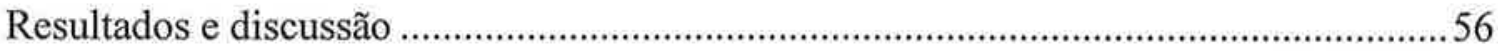

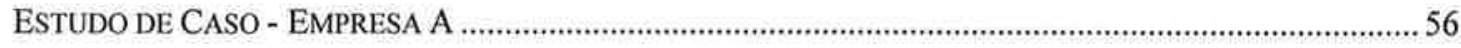

Um exemplo de aplicação: Projeto e construção de equipamento para geração de energia ........... 59

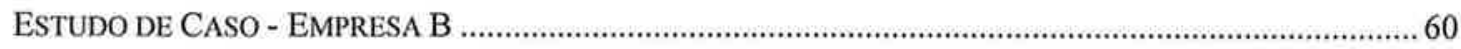

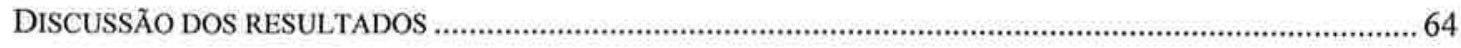

Empresa A

Empresa B

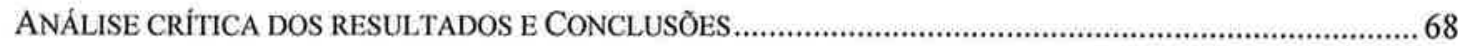

COMENTÁRIOS FINAIS E DIREÇÕES PARA PESQUISA FUTURA …………………………….................... 73

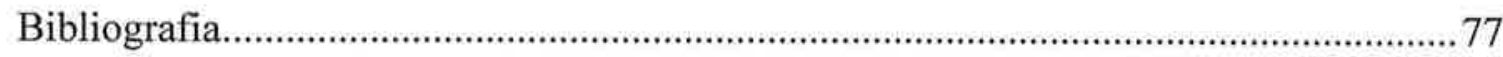


...ao Rei eterno, imortal, invisível, Deus único, honra e glória pelos séculos dos séculos...

(I Timóteo 1:17)

Para Beth, Ruben e Andre

Para meu pai, e para minha mãe, que não pôde ver este trabalho concluído 


\section{AGRADECIMENTOS}

Ao Professor Fleury, pela orientação, sempre oportuna e precisa.

Às empresas que permitiram a pesquisa de campo contida neste trabalho, pela oportunidade e acolhida. Em especial aos senhores Carlos Roberto Hohl, Sérgio Mascherpa, Alberto Tomiya, Manoel Conde e Divaldo Suzuki.

Aos professores Guilherme Ari Plonski e Francisco Cardoso, pelas sugestões e comentários.

Aos Professores Shimizu, Márcia e Paulino, às funcionárias da secretaria, pelo apoio à Pós Graduação.

Aos meus colegas, por vários motivos. João Batista, Roberto, Arthur, Carmen, muito obrigado (perdão aos demais pelas omissões).

Ao Conselho Nacional de Desenvolvimento Científico e Tecnológico (CNPq), pela bolsa de pesquisa que custeou este trabalho. 


\section{RESUMO}

O tema desta dissertação é a organização da Engenharia em empresas com múltiplas unidades. Discutimos a centralização e a descentralização das atividades de Engenharia utilizando o conceito da organização como sistema de processamento de informações. A partir desse ponto de vista, comparamos duas empresas multinacionais de diferentes setores industriais.

Concluímos que as organizações procuram um arranjo organizacional que equilibre as suas necessidades de processamento de informações com a respectiva capacidade de processamento que possuem. Concluímos também que a descentralização das atividades de Engenharia é influenciada pela complexidade da interface entre do produto com o usuário. 


\section{ABSTRACT}

This dissertation studies the engineering organizational structure in companies with multiple units. Starting from the concept of the organization as an information processing system, we study the centralization and decentralization of engineering activities, comparing two multinational companies, from different industries.

We finished this study concluding that companies seek organizational structures with informational processing capacity that match their corresponding informational processing requirements. We have also concluded that the decentralization of engineering activities is influenced by the complexity of the company's product/user interface. 


\section{ÍNDICE DE TABELAS}

Tabela 1: Quadro Comparativo das estruturas organizacionais ......................................17

Tabela 2: Perfis dos Gerentes Peso-leve e Peso-pesado...................................................19

Tabela 3: Padrões de Gestão de empresas com unidades em diversos países ..................28

Tabela 4: Comparação entre arranjos organizacionais da Engenharia

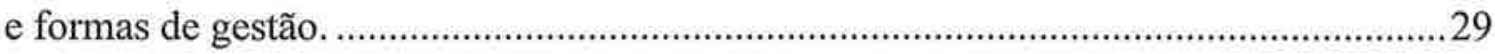

Tabela 5 - Tipos de empresas polares a serem pesquisadas …....................................54

Tabela 6 - Comparação entre as duas empresas pesquisadas ......................................... 71 


\section{ÍNDICE DE FIGURAS}

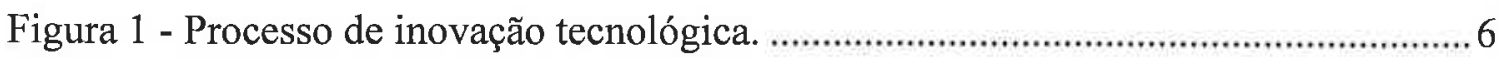

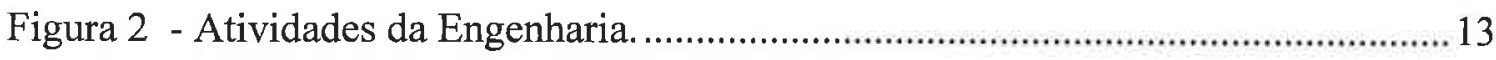

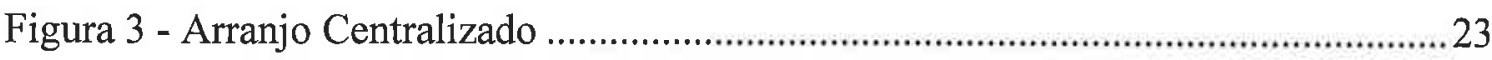

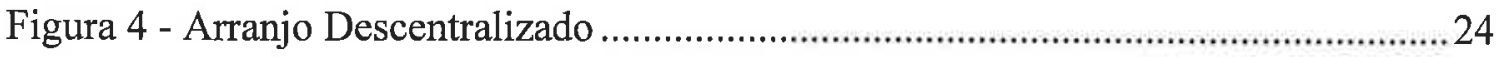

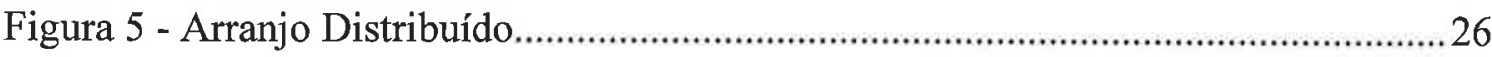

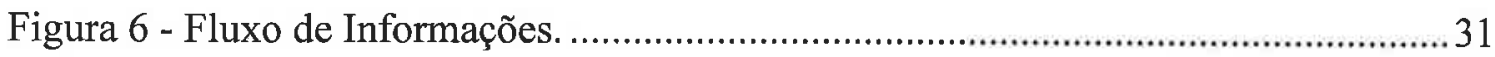

Figura 7 - Equilíbrio entre necessidade e capacidade

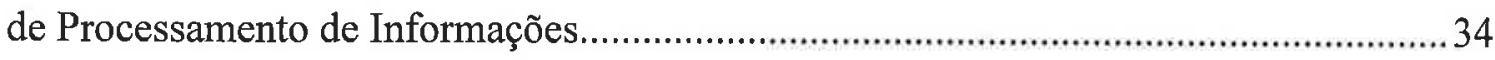

Figura 8: Matriz para comparação entre diferentes setores industriais .......................... 37

Figura 9 - Fatores geradores da necessidade de informações...........................................38

Figura 10 - Mecanismos básicos de coordenação e controle. ..............................................42

Figura 11 - Mecanismos adicionais de coordenação e controle........................................43

Figura 12 - Fatores de aumento da capacidade de processamento de informações. .......44 44

Figura 13 - Equilíbrio entre necessidade e capacidade

de processamento de informações e seus fatores geradores.........................................44

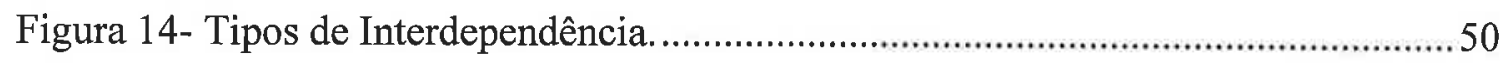

Figura 15 - Atividades da Engenharia local da empresa A ...........................................65

Figura 16 - Arranjo organizacional da Engenharia da empresa A ..................................66

Figura 17 - Divisão de atividades entre Engenharia local e central na empresa B.........67

Figura 18 - Arranjo organizacional da Engenharia da empresa B...............................67

Figura 19 - Posição de cada empresa na matriz de complexidade ................................69 


\section{INTRODUÇÃO}

O objetivo desse trabalho é contribuir para a discussão sobre as novas formas de organização da Engenharia, dentro do atual ambiente competitivo e globalizado. $O$ interesse específico deste estudo pela Engenharia começa a partir das seguintes constatações:

- A literatura destaca que, na prática das empresas norte-americanas no final da década de 70 e início da década de 80 (Hayes e Wheelwrigth, 1984), e das empresas industriais brasileiras até o final da década de 80 (Fleury e Plonski, 1994), as etapas de Manufatura e Engenharia não eram valorizadas do ponto de vista estratégico das corporações. As atividades comerciais, de marketing e financeiras eram consideradas mais importantes, devido em grande parte às condições do ambiente competitivo e econômico reinantes.

- A modificação desse ambiente, tanto a nível mundial, com a entrada de novos competidores e conseqüente acirramento da competição, como também no nível nacional (principalmente a partir dos anos 90) com a abertura às importações e retração de mercado, mostraram às empresas a necessidade de revalorizar a Manufatura. Assim a competência na Manufatura ganhou destaque, tanto na busca por lucratividade quanto na própria sobrevivência das empresas.

A busca por uma maior competência, que em seu primeiro momento concentrou-se na Manufatura se estende agora também às atividades à montante do processo de inovação tecnológica, ou seja, de Engenharia e Desenvolvimento. Dessa forma é esperado que deva existir hoje uma preocupação muito maior com o melhor desempenho das atividades de Engenharia dentro das empresas. 
Essa preocupação (expressa no esforço por melhorias em custo, qualidade, velocidade, flexibilidade e confiabilidade ${ }^{1}$ ) da Engenharia e Desenvolvimento, pode ser percebida por exemplo na busca por parte das empresas de novos arranjos organizacionais e técnicas de trabalho (por exemplo a Engenharia Simultânea e o QFD, Quality Function Deployment). No âmbito da indústria brasileira, temos estudos que confirmam o seu uso (veja por exemplo: Kruglianskas, 1993, Junqueira, 1994, Muniz, 1995, Santos, 1996).

O esforço por melhor desempenho nas atividades de Engenharia e Desenvolvimento também por ser percebido pelas diversas publicações recentes na literatura internacional sobre o tema (veja por exemplo Pugh, 1990, Clark e Fujimoto, 1991, Wheelwright e Clark, 1992, Susman, 1992, Rosenthal, 1992, Clausing, 1994), além dos inúmeros artigos em revistas técnicas e acadêmicas.

Em geral, o foco desses estudos está centrado na melhoria dos processos de desenvolvimento, na busca pelos arranjos organizacionais mais adequados e no uso de melhores técnicas e ferramentas. Mas na maioria deles a Engenharia é vista como um corpo único, ou seja, como se os processos de desenvolvimento fossem realizados em um único local. Ocorre no entanto ser cada vez mais freqüente que as empresas sejam constituídas por múltiplas unidades, e que a Engenharia esteja, em muitos casos, presente em diversas unidades.

Assim, nesses casos, além das já citadas preocupações com a melhoria no desempenho das atividades de desenvolvimento, existem ainda problemas adicionais, decorrentes da existência de múltiplas unidades. Por exemplo:

- Como escolher entre uma arranjo centralizado ou descentralizado entre as múltiplas unidades de Engenharia, de forma a obter o melhor desempenho global, e não somente localizado?

\footnotetext{
1 Para uma discussão mais detalhada sobre os critérios competitivos da manufatura, veja por exemplo Slack, 1993.
} 
- Qual a necessidade e o papel de uma unidade central de Engenharia?

- Como manter e disseminar conhecimento gerado em uma unidade e as informações entre as unidades locais de Engenharia?

Este estudo procura contribuir para o estudo da Engenharia focalizando especificamente o aspecto do arranjo organizacional entre múltiplas unidades, discutindo a questão da centralização/descentralização das atividades de desenvolvimento. Iniciamos este estudo escolhendo a seguinte pergunta de pesquisa: "Como as empresas com múltiplos departamentos de Engenharia estão se estruturando para competir no mercado globalizado?". Para respondê-la, , analisamos a dinâmica existente entre as diferentes unidades de Engenharia de duas empresas multinacionais com unidades instaladas no Brasil, usando o método do estudo de caso.

Para tanto, partimos da abordagem da empresa como uma organização voltada para o processamento de informações. A partir dessa abordagem, desdobramos nossa pergunta inicial em proposições específicas, posteriormente verificadas na pesquisa de campo. Terminamos esse trabalho com duas conclusões principais:

1. Encontramos evidência de que a escolha entre o arranjo centralizado ou o descentralizado dos departamentos de Engenharia é influenciada pelo tipo de produto e características de mercado que a empresa atende. Empresas que possuem a interface do produto com o usuário mais complexas têm maior necessidade de autonomia e capacidade técnica nas unidades locais, pois são elas as responsáveis pelo atendimento ao usuário. Nesses casos a escolha do arranjo descentralizado parece ser mais adequada.

2. Encontramos forte evidência que o arranjo organizacional escolhido por empresas bem-sucedidas é tal que equilibra suas necessidades de processamento de informações (oriundas da tarefa, ambiente externo e de suas próprias características internas) com a capacidade de processamento que é inerente ao seu arranjo organizacional. 
O trabalho está estruturado da seguinte forma: no primeiro capítulo discutimos a função Engenharia dentro do processo de inovação tecnológica, suas características e atividades específicas. No segundo, discutimos os arranjos organizacionais da Engenharia, tanto no nível interno à uma unidade quanto no nível inter-unidades. Encerramos o capítulo com alguns comentários sobre a gestão de empresas multinacionais. No terceiro capítulo, a partir do conceito de incerteza, definido como a diferença entre a quantidade de informação necessária para a realização de uma tarefa e a quantidade de informação disponível para realizá-la, é desenvolvido um esquema para o estudo dos arranjos organizacionais da Engenharia.

O quarto capítulo é dedicado à formulação da proposição de pesquisa a ser verificada, e o método de pesquisa utilizado para esse fim. São descritos os passos tomados até se chegar ao enunciado da proposição de pesquisa e é apresentada a justificativa da escolha do método e do tipo de empresas a serem estudadas. O quinto e último capítulo apresenta os Estudos de caso realizados, analisa e discute os resultados obtidos,as suas implicações, e é concluído com algumas sugestões para pesquisa futura. 


\section{CONCEITO E ATIVIDADES DA ENGENHARIA}

Na medida em que a palavra Engenharia pode ter diversas interpretações (uma formação acadêmica, um departamento dentro de uma empresa, uma categoria profissional), parece ser prudente iniciar o estudo discutindo o conceito de Engenharia que será utilizado ao longo deste trabalho. Para tanto, partimos do conceito de processo de inovação tecnológica. Conforme veremos neste capítulo, o estudo desse processo nos possibilita uma separação entre as atividades de Pesquisa e Desenvolvimento, Engenharia e Manufatura. Ao final, chegaremos a um conjunto de 7 atividades básicas da Engenharia, que serão úteis posteriormente em nosso estudo.

\section{O CONCEITO DE ENGENHARIA}

O processo de inovação tecnológica, ou seja, o conjunto de etapas percorridas pela descoberta ou invenção de algum artefato ou processo até chegar ao ponto de se tornar disponível à sociedade, tem três grandes fases:

- invenção, o descobrimento de novos conceitos,

- inovação, a operacionalização desses novos conceitos, e

- difusão, a colocação do conceito operacionalizado à disposição do mercado na forma de um novo produto ou processo.

Almeida (1981), estudando a relação entre tecnologia e mercado, utilizou três dimensões: econômica, institucional e funcional. O resumo de sua revisão conceitual, é concluído da seguinte forma: 
"A título de resumo, podemos dizer que o processo de ligação da tecnologia com o mercado tem sido tratado sob diversas denominações e ângulos, sendo a mais comum, ainda, a expressão processo de inovação. Esse processo tem três grandes fases: invenção, inovação propriamente dita e difusão; essas fases têm sido separadas, agrupadas e rearranjadas, mas permanecem essencialmente as mesmas. $A$ desagregação apresenta comumente as fases pesquisa básica, pesquisa aplicada, desenvolvimento, engenharia ou projeto, operação ou produção ou fabricação, e, utilização ou consumo ou mercado." (Almeida, 1981, p.53)

A desagregação do processo de inovação tecnológica em funções leva aos seguintes blocos:

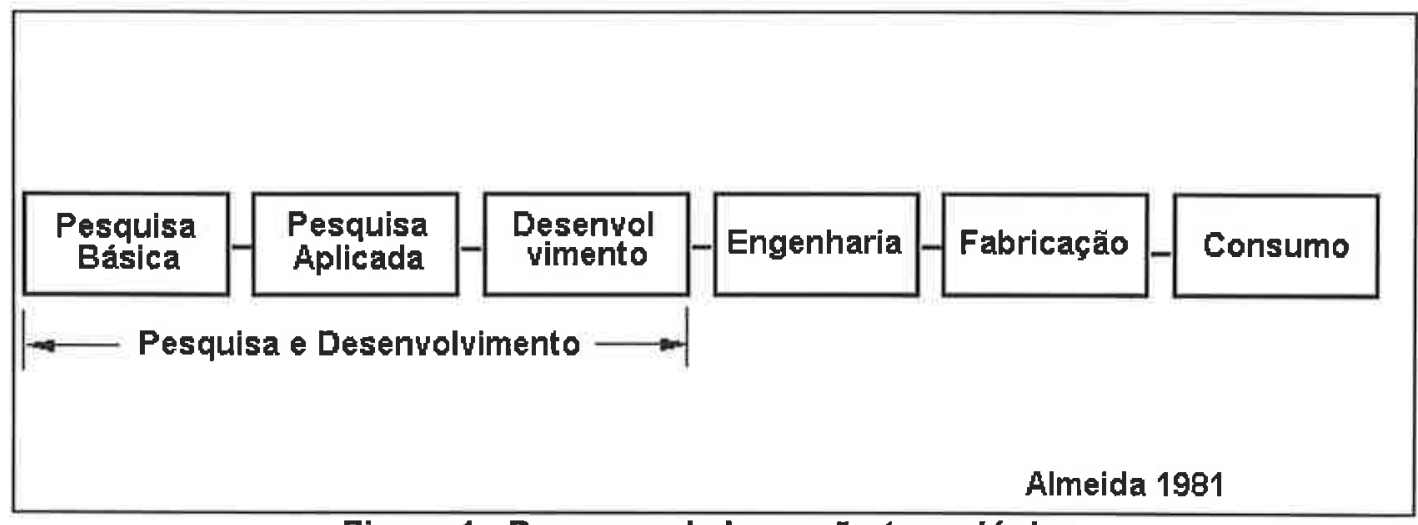

Figura 1 - Processo de inovação tecnológica.

Fonte: Almeida, 1981

As empresas em geral acabam agrupando os três primeiros blocos sob a denominação Pesquisa e Desenvolvimento (P\&D), conforme indicado na figura (Fleury, 1983). Essas fases podem ser detalhadas da seguinte forma:

"Os dois termos (P\&D) estão geralmente juntos e designam um conjunto de atividades de natureza criativa, realizadas normalmente de forma sistemática com o fim de aumentar o acervo de conhecimentos técnico-científicos e usar tal acervo no projeto $e$ realização de aplicações práticas. Considera-se a $P \& D$ composta de três subsistemas de atividades: pesquisa básica, pesquisa aplicada e desenvolvimento experimental. 
A pesquisa básica, também denominada pura ou fundamental é a investigação original, cujo objetivo se resume na expansão do conhecimento cientifico - não tem por objetivo aplicar os conhecimentos obtidos.

...A pesquisa aplicada difere um pouco da pesquisa básica em termos de procedimentos e metodologias. A distinção se estabelece, entretanto, nos objetivos. $A$ atividade de pesquisa aplicada é investigação original conduzida com o objetivo de se ganhar novos conhecimentos técnico-científicos tendo em vista uma aplicação prática.

...Por desenvolvimento experimental entende-se a atividade que objetiva a construção de protótipos elou a montagem de um processo experimental de produção, a partir de um amplo acervo de conhecimentos e técnicas oriundas da pesquisa elou da experiência prática pregressa. Assim . o desenvolvimento experimental é um trabalho sistemático, criativo, com fundamento em conhecimentos, práticas e técnicas diversas e dirigindo a obtenção de algum produto e/ou processo de produção. Entende-se entretanto que a atividade de desenvolvimento experimental cessa quando um protótipo ou linha piloto de produção é concluída e testada.

Daí em diante, até a obtenção de uma produção definitiva elou produto acabado, a atividade é definida como Engenharia (de produto/processo)" (Teixeira, 1983)

Dessa forma o papel da Engenharia é fazer a ligação entre uma atividade de longo prazo, voltada para a geração de novos conceitos, produtos e processos (a função P\&D) com uma atividade de ênfase prática e necessidade de resultados imediatos, voltada para a satisfação de uma demanda de mercado (a função Produção). A Engenharia procura gerar e organizar o "pacote tecnológico" que permite a fabricação de um produto (Fleury, 1983, p.4).

Barbieri (1990, p.60) comenta: 
"A Engenharia utiliza conhecimentos cientificos e tecnológicos para projetar $e$ construir novos produtos, equipamentos, subunidades e unidades produtivas inteiras, bem como para aperfeiçoar as existentes."

Engenharia é portanto, de acordo com esse ponto de vista: um conjunto de atividades que produz a capacitação necessária para a manufatura de produtos, através da reunião e organização de diversos conhecimentos, e da aplicação desses conhecimentos organizados no setor produtivo, possibilitando a produção de um novo tipo de bem ou aprimorando a fabricação dos já existentes.

Uma idéia comum, mas não necessariamente correta, é que cada uma das fases do processo de inovação é desenvolvida por uma instituição diferente. A Pesquisa Básica e a Aplicada seriam realizadas principalmente nas Universidades e Institutos de pesquisa, o Desenvolvimento nos Institutos de Pesquisa, a Engenharia em empresas de Engenharia e a Fabricação nas empresas de manufatura.

Uma empresa de manufatura ocupar-se-ia então única e exclusivamente da fabricação, o que é contestado pela prática de diversas empresas que dedicam considerável quantia de recursos à pesquisa e desenvolvimento, ou mais ainda, por aquelas que possuem somente as funções de marketing, desenvolvimento e distribuição, entregando toda a etapas de manufatura para terceiros. Da mesma forma, diversas empresas possuem seus próprios departamentos de Engenharia, onde realizam as aplicações necessárias aos seus processos produtivos, mesmo que às vezes não possuam atividades de Pesquisa e Desenvolvimento.

Uma dificuldade do processo de inovação tecnológica proposto na figura 1 é que a separação entre Pesquisa, Desenvolvimento e Engenharia, apesar de clara e didática, na prática das empresas não se revela tão evidente, apresentando muitas vezes pouca clareza na distinção entre cada função e nas interfaces entre elas. Por exemplo, Almeida (1981, p.80) coloca: 
“... Desenvolvimento e Engenharia se superpõe extensamente, no seu papel de criação de conhecimento tecnológico. A melhor diferenciação que podemos observar é quanto à destinação dos resultados da atividade: quando imediatamente dirigido à produção é Engenharia.... Engenharia produz Tecnologia, ligando os principios científicos ao projeto...."

Barbieri (1990, p.60) também faz a mesma afirmação :

"Os limites entre as fases de Engenharia e Desenvolvimento experimental não são facilmente identificados. .....De um modo geral, a fase de Engenharia começa quando os modelos e invenções já estão suficientemente completos, aperfeiçoados e em condições de serem transformados em produtos e processos, novos ou modificados, em escala normal de produção e comercialização."

Outro aspecto importante a ser lembrado é que o processo de inovação tecnológica define uma das fontes de informação da Engenharia, a técnica. Porém o trabalho da Engenharia depende de outra fonte de dados importante, pois o desenvolvimento de novos produtos é também resultado da estratégia de produto e mercado da empresa. A estratégia de produto/mercado preocupa-se em responder quatro perguntas básicas (Wheelwright e Clark, 1992, p.32-41):

- Que produtos devem ser oferecidos ao mercado?

- Quais serão os consumidores-alvo?

- Que canais de distribuição serão usados?

- Quais serão os atributos de diferenciação do produto em relação aos concorrentes?

A Engenharia trabalha portanto organizando o pacote tecnológico para a Manufatura, utilizando os conhecimentos provenientes do $\mathrm{P} \& \mathrm{D}$ e as informações provenientes do mercado. A correta interpretação dessas informações garante que o projeto realizado pela Engenharia seja adequado às necessidades do mercado que a empresa pretende atingir. 
O escopo deste estudo tem os seguintes limites:

- As atividades de manufatura não estão ligadas à nossa definição de Engenharia, assim como o planejamento, programação, controle, atividades de apoio e manutenção relacionados à manufatura.

- A Engenharia preocupa-se com a organização de conhecimentos para a manufatura.

- O pacote tecnológico que a Engenharia organiza é desenvolvido, entre outras fontes, a partir de informações do mercado que a empresa atende.

\section{As ATIVIDADES DA ENGENHARIA}

Para Barbieri (1990, p.61), entre outros, a Engenharia realiza os seguintes serviços: Estudos de viabilidade técnica e econômica, projeto básico, projeto construtivo ou executivo, construção e montagem, posta em marcha e início das operações. E pode ainda envolver os serviços de assistência técnica, manutenção e treinamento. Esta descrição expande a ação da Engenharia na direção da Manufatura dentro do processo de inovação tecnológica, ao colocar os serviços de construção, posta-em-marcha e início das operações como atividades da Engenharia. Por outro lado, em direção à outra extremidade do processo, não considera nenhuma atividade relativa à obtenção de informações de mercado.

Entre as diversas descrições de atividades de projeto e Engenharia, a de Pugh (1990) é bastante abrangente. Esse autor argumenta que praticamente todos os produtos são resultado da associação de diversos conhecimentos e técnicas, de engenharia ou não, e necessitam da contribuição de diversas pessoas e áreas, resultando em um mix 
praticamente único (idem, p.vii). Por esse motivo, esse autor tem a preocupação explícita de formular um conjunto de atividades para a Engenharia de grande amplitude de alcance.

Para Pugh (1990), a formação oferecida aos engenheiros prioriza o conhecimento específico em uma área, o que faz com eles normalmente pensem somente a partir desse ponto de vista, trabalhando com o que chama de Projeto Parcial (referente à cada área de conhecimento). Para contornar essa limitação, ele formula conceito de Projeto Total, que se preocupa com todas áreas de conhecimento utilizadas no produto e a sua integração dentro do projeto. O chamado Projeto Total é definido da seguinte forma:

"A atividade sistemática necessäria para, partindo da identificação das necessidades do mercado e dos usuários, possibilite a venda de produtos que satisfaçam essas necessidades. Portanto é uma atividade que envolve produtos, processos, pessoas e organização." (idem).

A definição de Projeto Total tenta expandir a preocupação do engenheiro projetista, em se preocupar somente com a especificação, o projeto conceitual e de detalhamento do produto (as fases "tecnológicas" do projeto), pela proposta de um núcleo para o projeto, dividido em fases, começando com a análise do mercado e indo até a distribuição e venda do produto. As fases do projeto tratam dos seguintes aspectos (idem):

\section{Mercado}

Avaliação das necessidades do mercado e dos usuários, através de informações provenientes de diversas fontes

\section{Especificação do produto}

Especificação de Projeto do Produto, um conjunto de informações que orienta todas as etapas subseqüentes, sendo a referência básica do projeto.

\section{Projeto conceitual}

Geração de soluções que atendam à Especificação de Projeto do Produto, e avaliação e seleção da melhora alternativa, a partir das soluções técnicas disponíveis. O Projeto conceitual traduz a visão geral do produto, como um conjunto de sub-sistemas e componentes. 


\section{Projeto detalhado}

Projeto dos subsistemas e componentes do produto, usando-se o conceito de Projeto Parcial para cada parte.

\section{Manufatura}

Projeto do processo, com integração e envolvimento da manufatura durante toda a fase de projeto, evitando problemas com atrasos e aumento do número de modificações.

\section{Vendas}

Estabelecimento do retorno da informação do mercado para a primeira fase do Projeto, compreendendo a distribuição, venda, serviços pós-venda, etc.

As atividades da Engenharia, conforme esta descrição, são:

- A avaliação de necessidades de mercado, que orienta o desenvolvimento do produto.

- A fase de especificação, onde as necessidades e requisitos de mercado são traduzidos para parâmetros técnicos.

- A busca de soluções (projeto conceitual) que reunam as necessidades do mercado ao estoque de conhecimento tecnológico disponível.

- O desenvolvimento do projeto básico e detalhado do produto ou processo, possibilitando sua fabricação.

- O projeto do processo de fabricação, integrando o projeto do produto com a fabricação e entrega ao mercado.

- O acompanhamento da colocação do produto no mercado e dos serviços de pós-venda.

Esquematicamente: 


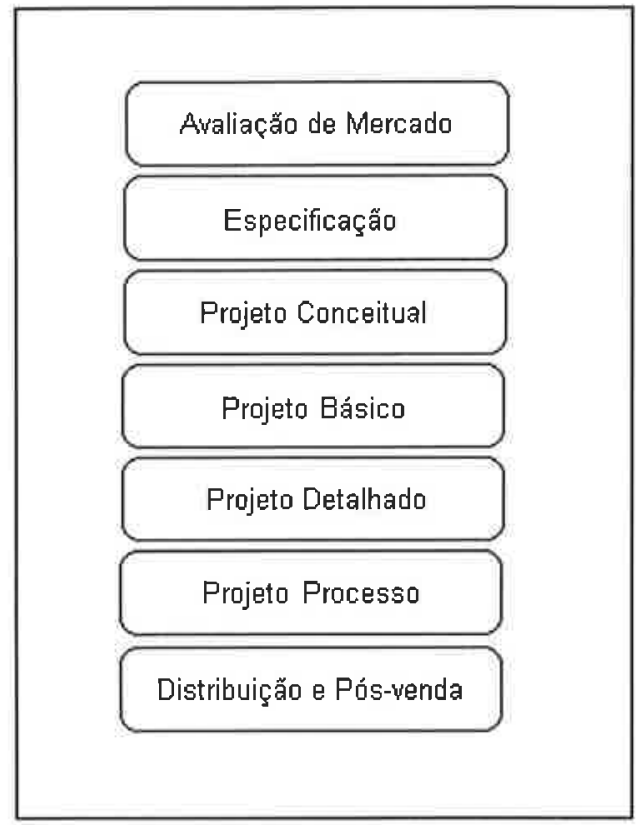

Figura 2 - Atividades da Engenharia.

Fonte: Adaptado de Pugh (1990)

A figura 2 define um conjunto de atividades para Engenharia bastante completo, com atividades técnicas, como as etapas de projeto básico. detalhado e de processo, assim como atividades relativas à busca e acompanhamento das informações de mercado, nas etapas de avaliação de mercado, distribuição e pós-venda.

O esquema pode transmitir a impressão de que as atividades devam ser executadas de forma estritamente seqüencial, o que não é necessariamente correto. Algumas atividades podem ser realizadas simultaneamente ou com superposição em relação à outras, como acontece na Engenharia Simultânea. Por exemplo, o projeto do processo pode ser realizado de forma paralela ao projeto básico e detalhado do produto, usando o conceito de DFM (Design for manufacturing) (Susman, 1992, p.4).

Pretendemos utilizar o conjunto definido no esquema da figura 2 como um padrão para comparação das diferentes configurações de arranjos organizacionais entre unidades de Engenharia. Conforme vamos detalhar mais adiante, de acordo com a configuração organizacional e o grau de interdependência entre as unidades, a organização pode optar 
por executar todas as atividades nas unidades locais de Engenhariam ou algumas nas unidades locais e outras na unidade central. 


\section{OS ARRANJOS ORGANIZACIONAIS DA ENGENHARIA}

O objetivo deste capítulo é posicionar este estudo dentro do atual estágio de discussão a respeito dos arranjos organizacionais utilizados para a Engenharia. Iniciamos a revisão analisando os arranjos organizacionais mais freqüentes para uma unidade de Engenharia local. Estudaremos a estrutura funcional, a estrutura por projetos, a estrutura matricial e as variações de cada uma delas.

Em seguida, constatando que, além dos aspectos organizacionais propriamente ditos, existe hoje também toda uma discussão a respeito das técnicas utilizadas no desenvolvimento de novos produtos (Engenharia Simultânea, QFD, DFM) faremos uma breve revisão sobre o assunto, pois entendemos que abordar o assunto Engenharia sem mencioná-las seria desconsiderar uma área importante do conhecimento atual.

Passaremos então a estudar as formas de arranjo organizacional entre diferentes unidades de Engenharia. A nosso ver os assuntos de maior interesse nesse nível são: a existência ou não de um órgão de Engenharia central, e as suas funções, e o grau de autonomia e as funções da unidades locais de Engenharia.

Finalmente, como em geral as empresas multiunidades, foco do nosso estudo, estão presentes em diversos países, isto é, são multinacionais, inserimos uma breve discussão sobre as formas de gestão desse tipo de empresa, utilizando os conceitos de empresa global, multinacional, internacional e transnacional de Bartlett e Ghoshal (1992). 


\section{ARRANJOS ORGANIZACIONAIS DA ENGENHARIA}

\section{Arranjos internos a uma unidade de Engenharia}

Os arranjos organizacionais básicos da Engenharia encontrados na maioria das empresas são o funcional, o por projetos e o matricial (O'Connor, 1994, p.62). O arranjo funcional, uma forma tradicional de organização, coloca cada especialidade da Engenharia, cada área de conhecimento (projeto elétrico, projeto mecânico, manufatura, suporte a cliente, etc.), em departamentos diferentes, isto é, todas as pessoas que se utilizam de um mesmo tipo de conhecimento são agrupadas na mesma unidade. Os engenheiros são relativamente especializados e normalmente não existe um responsável geral em cada projeto, sendo os gerentes de cada especialidade os responsáveis pela alocação de recursos e pelo desempenho de suas funções (Clark e Fujimoto, 1991).

Em geral esse tipo arranjo se caracteriza pelo alto nível de formalização da estrutura, pela unidade de comando, alto grau de especialização dos técnicos e uso da comunicação vertical (Vasconcellos e Hemsley, 1986, p.6). Seus pontos fortes são a unicidade de comando e autoridade, facilidade de avaliação do desempenho dos técnicos e desenvolvimento de conhecimento especializado em uma área (Wheelwright e Clark, 1992). Porém quando um arranjo desse tipo precisa lidar com diversos projetos simultâneos, é comum que surjam problemas de coordenação e comunicação, assim como a falta de visão global dos projetos.

As duas outras formas, por projetos e matricial, são consideradas formas inovativas, caracterizadas pelo baixo nível de especialização, multiplicidade de comando, diversificação elevada e uso de comunicação horizontal e diagonal (Vasconcellos e Hemsley, 1986, p.23). Esses arranjos podem ser colocados em um contínuo, onde uma extremidade é ocupada pelo arranjo funcional, a outra pelo por projetos e o arranjo matricial, como uma mistura entre os dois primeiros, entre os dois (PMBOK, 1994). 
O arranjo por projetos é a forma oposta ao arranjo funcional. Todas as pessoas envolvidas em um projeto, independentemente de sua especialidade, são reunidas em uma mesma unidade, e devotam todo o seu tempo a um único projeto. Esse tipo de arranjo tem a vantagem de facilitar o trabalho de equipe e a comunicação, pois as fronteiras entre departamentos são eliminadas. Entretanto surgem problemas como balanceamento de carga de trabalho entre equipes, diluição do conhecimento e dificuldades de atualização dos especialistas (O’Connor, 1994, p.62).

$\mathrm{O}$ arranjo matricial tenta fazer um balanço entre as vantagens e desvantagens dos dois arranjos anteriores. A estrutura matricial baseia-se na funcional, mas com a sobreposição de uma estrutura por projetos, onde os responsáveis de cada projeto têm sob sua direção especialistas de cada área, que lhe são designados pelos gerentes de cada área funcional (O'Connor, 1994, p.63). O arranjo matricial, por ser o resultado da combinação de duas outras estruturas, pode assumir diversas configurações diferentes, conforme haja predominância de uma ou outra estrutura. De acordo com o grau de predominância da estrutura funcional, a matriz pode variar de fraca a forte. Aquela que possui a dosagem aproximadamente igual dos dois arranjos é chamada de matriz balanceada ou pura (Vasconcellos e Hemsley, 1986, p.53 e PMBOK, 1994)

Colocadas lado a lado, essas estruturas apresentam o seguinte quadro comparativo:

\begin{tabular}{|c|c|c|c|c|c|}
\hline & Funcional & $\begin{array}{c}\text { Matriz } \\
\text { Fraca }\end{array}$ & $\begin{array}{c}\text { Matriz } \\
\text { balanceada }\end{array}$ & Matriz Forte & Projetos \\
\hline $\begin{array}{c}\text { Autoridade do gerente } \\
\text { de projeto }\end{array}$ & $\begin{array}{c}\text { quase } \\
\text { nenhuma }\end{array}$ & limitada & $\begin{array}{c}\text { baixa a } \\
\text { moderada }\end{array}$ & $\begin{array}{c}\text { moderada } \\
\text { a alta }\end{array}$ & $\begin{array}{c}\text { alta ou } \\
\text { total }\end{array}$ \\
\hline $\begin{array}{c}\text { Proporção de pessoal } \\
\text { alocado por tempo } \\
\text { integral ao projeto }\end{array}$ & $\begin{array}{c}\text { praticamen } \\
\text { te nenhum }\end{array}$ & $0-25 \%$ & $15-60 \%$ & $50-95 \%$ & $85-100 \%$ \\
\hline $\begin{array}{c}\text { Dedicação do gerente } \\
\text { de projetos }\end{array}$ & parcial & parcial & integral & integral & integral \\
\hline $\begin{array}{c}\text { Dedicação da equipe } \\
\text { administrativa do } \\
\text { projeto }\end{array}$ & $\begin{array}{r}\text { parcial } \\
\text { Tabela 1: Quadro Comparativo das estruturas organizacionais } \\
\text { Fonte: PMBOK, 1994 }\end{array}$ & integral & integral \\
\hline
\end{tabular}


Outra variação de estrutura organizacional para o desenvolvimento de produtos são as chamadas estruturas de equipe peso-leve (light weight team), equipe peso-pesado (heavy weight team) e equipe autônoma (tiger team), descritas por Clark e Fujimoto (1991, p.253-256) e Wheelwright e Clark (1992, p.190-196). Essas estruturas são variações da estrutura funcional, com a adição de um gerente de projetos responsável pela coordenação e a formação de equipes de projetos.

$\mathrm{Na}$ estrutura de equipe peso-leve, a organização permanece basicamente funcional, com a adição de um gerente de produto, que coordena as atividades de desenvolvimento de um projeto através do contato com pessoal de ligação de cada especialidade. Nesse tipo de estrutura, o gerente de projeto, usualmente um engenheiro ou gerente de marketing, não tem acesso direto ao pessoal envolvido no projeto, somente com o pessoal de ligação, e ocupa uma posição hierárquica inferior aos dos gerentes de cada departamento. Sua função principal é a de coordenação e auxílio na resolução de conflitos entre departamentos (Clark e Fujimoto, 1991, p.254-255 e Wheelwright e Clark, 1992, p.193).

A estrutura de equipe peso-pesado, embora também basicamente funcional, possui um gerente do projeto com acesso direto ao pessoal envolvido no trabalho. Ele ocupa uma posição hierárquica equivalente aos gerentes dos departamentos (superior portanto ao de um gerente peso-leve) e é responsável não somente pela coordenação das atividades, mas também, pelo planejamento e desenvolvimento conceitual do produto. Usualmente a equipe base do projeto fica diretamente ligada ao gerente peso-pesado (idem, p.255 e idem, p.194). Os perfis dos gerentes de projetos peso-leve e peso-pesado podem ser comparado na tabela a seguir: 


\begin{tabular}{|c|c|c|}
\hline & Peso-leve & Peso-pesado \\
\hline Amplitude de coordenação e responsabilidade & limitada & extensa \\
\hline Duração da responsabilidade & limitada & extensa \\
\hline Contato com a equipe de trabalho & limitada & extensa \\
\hline Contato direto com o consumidor & limitada & extensa \\
\hline Papel na resolução de conflitos & limitada & extensa \\
\hline Influência no marketing e manufatura & limitada & extensa \\
\hline
\end{tabular}

Tabela 2: Perfis dos Gerentes Peso-leve e Peso-pesado

Fonte: Adaptado de Wheelwright e Clark, 1992

Na terceira forma de organização, a equipe autônoma, técnicos das diferentes áreas funcionais são formalmente deslocados à equipe de projetos, passando a responder unicamente ao gerente de projetos, normalmente uma pessoa de alto nível dentro da organização (um "peso-pesado"). A equipe tem autonomia total para desenvolver o seu projeto, não precisando inclusive obedecer às práticas e procedimentos usuais da organização (Wheelwright e Clark, 1992, p.196).

A grande vantagem desse tipo de estrutura é o foco no projeto, o que resulta normalmente em um desenvolvimento rápido e eficiente. Por outro lado, a equipe, por sua autonomia, tem a tendência de projetar todas as partes do produto, deixando de utilizar projetos existentes e tornando difícil a padronização com os produtos em linha. Muitas vezes também o retorno dos técnicos às suas posições na estrutura funcional é difícil, o que faz com que essas equipes sejam muitas vezes o embrião de novas unidades de negócio, ou terminem por provocar alta rotatividade ao final do projeto (idem, p.196).

As diversas variações de arranjos procuram equilibrar a necessidade de coordenação entre as diversas áreas envolvidas com o conhecimento específico de cada uma delas. As estruturas de equipes peso-leve e peso-pesado são alternativas que procuram conferir à estrutura funcional um maior grau de coordenação e foco em cada projeto, 
sem cair na complexidade da estrutura matricial, enquanto a alternativa da equipe autônoma de projeto parece mais apropriada à produtos inovadores dentro da organização.

\section{A ENGENHARIA SIMULTÂNEA}

A Engenharia Simultânea (ES) é considerada uma abordagem inovadora para o desenvolvimento de produtos (Kruglianskas, 1993), e é descrita como: desenvolvimento do produto e do processo de forma simultânea e integrada (Junqueira, 1994), a criação de novos produtos bem-sucedidos através do uso precoce dos recursos e experiência da empresa no projeto, desenvolvimento, marketing, manufatura, serviços e vendas (Shina, 1991), trabalho em grupo, adicionado de projeto assistido por computador (CAD) e ferramentas de engenharia e manufatura (Rosenblatt e Watson, 1991).

Uma definição consagrada, citada pela maioria das publicações, foi elaborada pelo DARPA (Defense Advanced Research Projects Agency- USA) em 1986: "Engenharia Simultânea é um enfoque sistemático para o projeto integrado e concorrente de produtos e de seus processos correlatos, incluindo manufatura e suporte. Este enfoque pretende que os responsáveis pelo desenvolvimento considerem todos os elementos do ciclo de vida do produto, desde a sua concepção até o seu descarte, incluindo qualidade, custo, cronograma e requisitos do usuário" (Carter e Baker, 1992).

De forma simplificada a ES pode ser entendida como a substituição do conceito de desenvolvimento serial, onde cada departamento faz sua parte após a conclusão da parte imediatamente anterior, pelo conceito de uma equipe multifuncional que desenvolve o projeto com a participação de todos os departamentos envolvidos no projeto, comercialização, manufatura e suporte do produto. $\mathrm{Na}$ realidade não pode ser 
considerado um conceito novo pois diversas empresas japonesas , por exemplo a Toyota e a Honda, já utilizavam essa técnica, sem esse rótulo, há muitos anos (Vesey, 1991).

Clausing (1994, p.28) resume a ES em duas áreas: melhoria do processo de desenvolvimento e melhoria no trabalho em equipe. O processo de desenvolvimento é aprimorado pelo uso de trabalho simultâneo, pelo foco na qualidade, custo e entrega, ênfase na satisfação do cliente e pelo uso do benchmarking. A melhoria no trabalho em equipe é conseguida por uma organização mais integrada, maior envolvimento e autonomia dos participantes e pelo desenvolvimento de melhores relações com os fornecedores, inclusive com a sua participação no projeto do produto.

A ES foi implementada pelas empresas primeiramente para reduzir o tempo de projeto de um novo produto e para diminuir o acúmulo de esforços na fase de implantação, quando ocorre a transferência de documentação e informações para a manufatura, decorrente das necessidades de revisões e reformulações. Ela é vista como uma forma de reorganização da empresa para melhor explorar as potencialidades de equipamentos e software para desenvolvimento de produtos (Kruglianskas, 1993).

No sistema tradicional de organização do desenvolvimento de produto e processo, conhecido como "jogue por cima do muro" (Clausing, 1994, p.10) ou estrutura de "silos funcionais" (Rosenthal, 1992), a possibilidade de sobrecarga e atraso é muito grande, devido por um lado ao próprio volume de informações a serem processadas, e por outro pela limitação da capacidade de transmissão, devido ao próprio modo de trabalho.

No desenvolvimento tradicional (seqüencial), as interações entre os engenheiros são limitadas a momentos específicos e sob condições bem controladas. Por exemplo, um engenheiro de projeto só apresenta seu trabalho após ter um primeiro desenho pronto (Fotta e Daley, 1993), o que limita a capacidade de transmissão das informações entre os setores envolvidos.

A ênfase no chamado trabalho concorrente da Engenharia Simultânea, onde um grupo composto de diversos especialistas, com visões diferentes sobre o produto e o processo, 
trabalha simultaneamente, comunicando-se com freqüência, permite que capacidade de transmissão e processamento de informações seja aumentada, pelo contato freqüente e direto dos técnicos envolvidos ou pelo uso de sistemas de $\mathrm{CAD} / \mathrm{CAE}$, freqüentemente associados à ES. Podemos dizer pelo mesmo motivo que a ES promove uma redução do uso dos canais tradicionais de comunicação, como por exemplo a hierarquia.

A preocupação implícita na prática da ES com uma melhor comunicação nos processos de desenvolvimento de produtos e processos mostra a importância do fluxo de informações na Engenharia.. Além da ES, outras práticas e métodos podem melhorar o fluxo de informações, como por exemplo o QFD (Quality Function Deployment). O QFD “é um sistema que traduz as necessidades dos clientes em exigências apropriadas para a empresa, em cada estágio do ciclo de desenvolvimento do produto, desde a pesquisa e o desenvolvimento até a engenharia, a produção, o marketing, as vendas e a distribuição." (Eureka e Ryan, 1993).

As diversas versões do QFD são usualmente classificadas em: versão de Akao (a quem se atribui o método), versão do American Supplier Institute e a versão de King (Santos, 1996) ${ }^{2}$. Todas as versões fazem uso de um conjunto de matrizes, cuja finalidade básica é auxiliar o projeto de um produto pela tradução das expectativas dos seus usuários em requisitos, critérios e especificações para a sua fabricação. Busca-se com o QFD tanto a melhoria dessa tradução quanto o ganho em velocidade e integração entre os diversos departamentos envolvidos.

Segundo Santos (1996), nem as técnicas empregada pelo QFD nem a mecânica de integração entre elas são propriamente novas. Algumas estão em uso em diversas empresas. O principal fator para o seu sucesso não reside tanto na originalidade de suas propostas, mas na sua capacidade de integrar de forma consistente teorias e práticas conhecidas.

\footnotetext{
${ }^{2}$ Para maiores detalhes sobre essas versões, consulte a referência indicada, onde são apresentadas e discutidas em detalhe.
} 


\section{Arranjos organizacionais entre unidades de Engenharia}

Empresas que possuem diversas unidades produtoras, em diferentes países ou regiões, freqüentemente possuem departamentos de Engenharia em cada uma dessas unidades. As formas organizacionais mais comuns encontradas, definindo o grau de relacionamento entre as unidades e a existência ou não de um órgão central de Engenharia, são: a centralização, a descentralização e a forma distribuída.

A centralização é a forma mais antiga de todos os arranjos. O poder de decisão e a responsabilidade se concentram em um único indivíduo ou em um pequeno grupo (Vasconcellos, 1979). Um arranjo centralizado é aquele em que a empresa concentra em sua matriz a maior parte das atividades de Engenharia, ficando para as unidades locais somente os trabalhos de adaptação dos produtos e processos para as condições locais de cada unidade. Neste caso as unidades locais são pequenas e dependentes da Engenharia central.

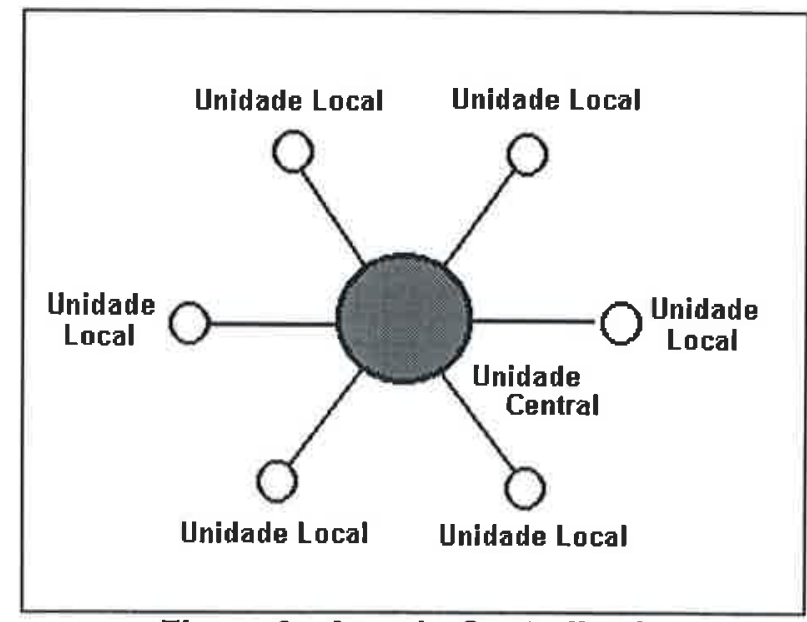

Figura 3 - Arranjo Centralizado

À medida em que a organização cresce, a manutenção do mesmo nível de centralização pode tornar-se difícil, pois o crescimento traz consigo o aumento da complexidade e diversificação dos problemas técnicos e administrativos. Nestes casos, a organização 
pode optar por descentralizar a tomada de decisões, tornando as suas operações mais dinâmicas.

A descentralização pode ser de autoridade, de atividade ou funcional. A descentralização de atividade ocorre quando uma mesma tarefa é realizada em diferentes unidades da organização. Se essas unidades, além de realizarem essa tarefa, possuírem também poder de decisão, então há também descentralização de autoridade, e se hierarquicamente os responsáveis por essas tarefas responderem aos chefes de suas respectivas unidades, e não ao órgão central, ocorre a descentralização funcional (Vasconcellos, 1979).

Algumas vantagens de uma estrutura descentralizada são: maior velocidade resposta às necessidades da unidade, maior adequação às necessidades da unidade, desenvolvimento de capacidade gerencial local.. Porém existem também desvantagens, como: possibilidade de capacidade ociosa, dificuldade de padronização entre as unidades, maior dificuldade de coordenação em atividades e duplicação de atividades (idem). Em um arranjo descentralizado, as unidades locais de Engenharia ganham força e realizam a maior parte das tarefas referentes ao projeto, podendo variar no grau de interdependência e relacionamento entre as unidades.

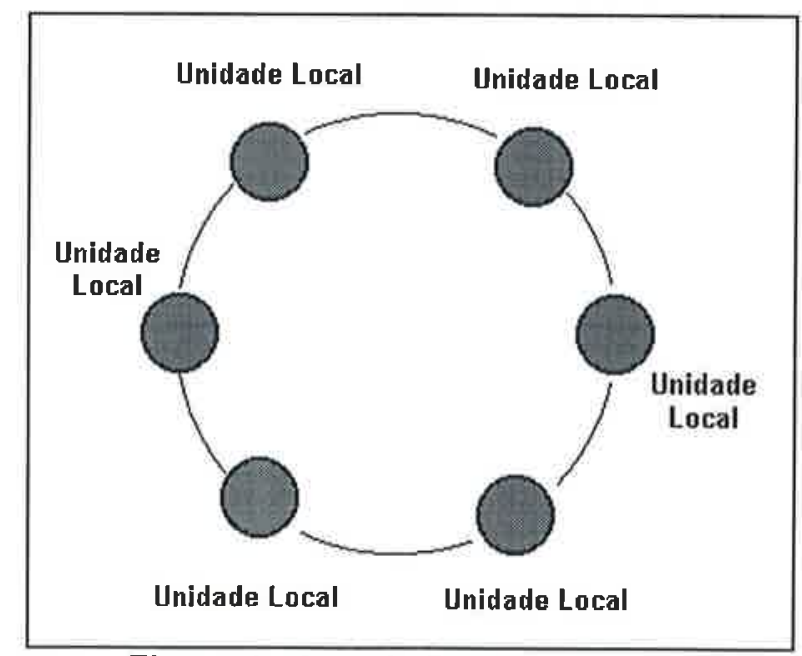

Figura 4 - Arranjo Descentralizado 
A descentralização pode levar à fragmentação da organização $e$ falta de coordenação. Porém a pressão por rapidez, controle de qualidade na origem e prestação de melhores serviços aos clientes têm forçado as empresas a optarem por ela (Galbraith e Lawler, 1995, p. 252). Tentando escapar de alguns problemas do arranjo descentralizado, algumas empresas têm adotado uma forma chamada organização distribuída. Segundo Galbraith e Lawler (1995, p.252-253), a organização distribuída:

"tem esse nome pela analogia com a computação distribuída. Originalmente, a maior parte da computação das organizações estava centralizada em mainframes. Mais tarde apareceu a alternativa de distribuir o poder do computador através da organização, pelo uso de computadores pessoais, workstations e minicomputadores. Mais recentemente, a tecnologia de redes têm permitido novas formas acesso, formando a rede distribuída.

Da mesma forma, algumas atividades eram originariamente centralizadas $e$ executadas na matriz da organização. O modelo distribuído toma essas atividades empresariais e as distribui para os melhores locais para sua execução... Dessa forma, as atividades são distribuídas em toda a organização. Os locais são conhecidos como centros de excelência ou líderes divisionais de responsabilidade.

A organização distribuída descentraliza uma atividade ao transferi-la da matriz para uma divisão ou unidade de negócios. Portanto, a atividade é executada perto dos acontecimentos....A organização distribuída centraliza ou consolida a atividade, de modo que ela ainda é executada num só lugar ou em poucos lugares...."

Ao contrário de uma organização descentralizada, a organização distribuída concentra algumas atividades em determinadas unidades, e diferentemente de uma organização centralizada, essas unidades não se localizam fisicamente em um único local e estão mais próximas do mercado do que o órgão central. Em um arranjo distribuído, a empresa escolhe para cada linha de produtos, um centro de excelência de Engenharia, que se torna responsável pelo desenvolvimento dos projetos desse produto, e pela difusão e suporte às outras unidades. 


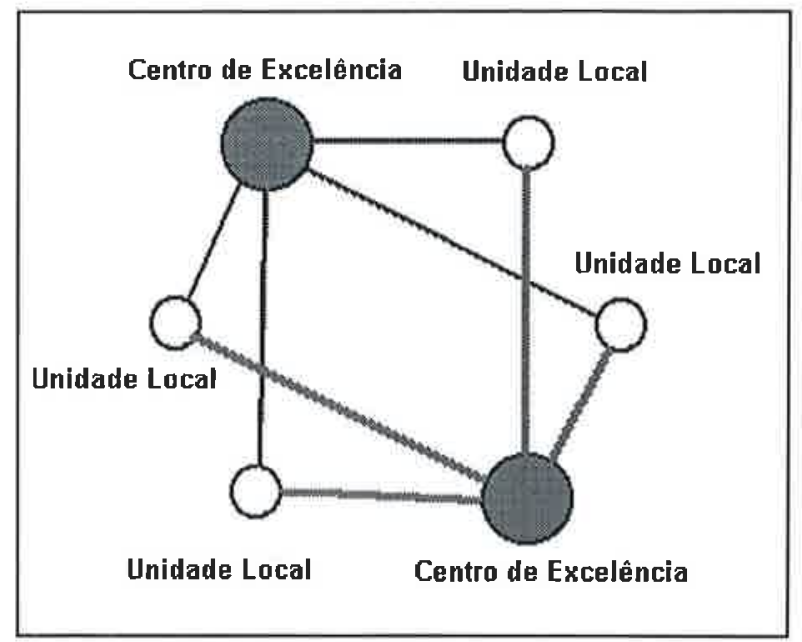

Figura 5 - Arranjo Distribuído

Os critérios para a escolha das unidades que passam a ser centros de excelência podem ser: exigências de governos locais, existência de capacitação diferenciada em uma especialidade em um país ou região ou existência de níveis de concorrência mais elevados em determinadas localidades (Galbraith e Lawler, 1995, p.254).

O arranjo organizacional distribuído tem também algumas dificuldades. Por exemplo: a atividade distribuída, localizada no centro de excelência, precisa ser avaliada e premiada por critérios aceitos e aprovados pelas outras unidades locais. O centro de excelência precisa aprender a raciocinar de forma global, pensando nas outras unidades, além de serem também necessárias mudanças de caráter geral na empresa, como por exemplo no planejamento, na avaliação e nos sistemas de informação corporativos (idem, p.254).

\section{Gestão de empresas multinacionais: alguns conceitos importantes}

Podemos identificar a grosso modo dois padrões básicos de gestão de empresas multinacionais. De um lado o tipo multidoméstico, onde a empresa reproduz réplicas de suas atividades em cada país onde se instala. Do outro, o tipo global, onde a empresa 
centraliza operações e tarefas administrativas e comercializa seus produtos em todo o mundo (Chiesa, 1996).

Nas empresas globais, os recursos da empresa-mãe são utilizados para gerar inovações que serão utilizadas em todo o mundo. A tecnologia é transferida do centro para as unidades locais, onde algumas adaptações são realizadas de forma a adequar o produto ao mercado local. Em empresas multidomésticas, as unidades locais usam seus próprios recursos e capacidades para criar inovações em resposta às demandas do mercado local (idem).

Bartlett e Ghoshal (1992) ampliam essa classificação da seguinte forma:

- Empresas globais - Historicamente, a primeira forma de estrutura utilizada por empresas que lançaram operações internacionais. A preocupação básica desse tipo de empresa é com a obtenção de vantagem em custo, centralizando fortemente as decisões operacionais e estratégicas. Para essas empresas, 0 mercado mundial é analisado como um todo global, e as operações locais são uma forma de melhorar a eficiência de seus processos produtivos.

- Empresas multinacionais - Surgiram nas duas décadas precedentes à II Guerra e caracterizam-se por uma preocupação forte com a presença local, procurando ter grande sensibilidade e receptividade aos mercados característicos de cada nação.

- Empresas Internacionais - Surgidas após a II Guerra. Nessas empresas a estratégia baseia-se principalmente na transferência e adaptação do conhecimento e habilidades da empresa-mãe aos mercados locais. A geração de conhecimento acontece na empresa-mãe sendo depois difundido ao mercado mundial.

Segundo Bartlett e Ghoshal, o novo padrão emergente para as empresas seria o transnacional, onde a empresa teria simultaneamente a preocupação com a eficiência de suas operações, a receptividade aos mercados locais e o aprendizado em cada 
unidade. Colocados lado a lado em uma tabela, esses modelos de empresas apresentam as seguintes características:

\begin{tabular}{|c|c|c|c|c|}
\hline & Global & Internacional & Transnacional $^{3}$ & Multinacional \\
\hline $\begin{array}{l}\text { Configuração de } \\
\text { ativos e recursos }\end{array}$ & Centralizada & $\begin{array}{l}\text { Algumas } \\
\text { competências } \\
\text { básicas } \\
\text { centralizadas, } \\
\text { outras } \\
\text { descentralizadas }\end{array}$ & $\begin{array}{l}\text { Dispersa, } \\
\text { unidades } \\
\text { interdependentes } \\
\text { e especializadas. }\end{array}$ & $\begin{array}{l}\text { Descentralizada } \\
\text { Auto-suficiência } \\
\text { das unidades } \\
\text { locais }\end{array}$ \\
\hline $\begin{array}{l}\text { Papel das } \\
\text { unidades locais }\end{array}$ & $\begin{array}{l}\text { Implantar as } \\
\text { estratégias da } \\
\text { empresa-mãe }\end{array}$ & $\begin{array}{l}\text { Adaptar e } \\
\text { alavancar as } \\
\text { competências da } \\
\text { empresa-mãe }\end{array}$ & $\begin{array}{l}\text { Contribuições } \\
\text { diferenciadas das } \\
\text { unidades locais e } \\
\text { operaçōes } \\
\text { mundiais } \\
\text { integradas }\end{array}$ & $\begin{array}{l}\text { Sentir e explorar } \\
\text { as oportunidades } \\
\text { locais }\end{array}$ \\
\hline $\begin{array}{l}\text { Desenvolvimento } \\
\text { e difusão do } \\
\text { conhecimento }\end{array}$ & $\begin{array}{l}\text { Conhecimento } \\
\text { desenvolvido e } \\
\text { mantido no centro }\end{array}$ & $\begin{array}{l}\text { Conhecimento } \\
\text { desenvolvido no } \\
\text { centro e } \\
\text { transferido para as } \\
\text { unidades no } \\
\text { exterior }\end{array}$ & $\begin{array}{l}\text { Conhecimento } \\
\text { desenvolvido em } \\
\text { conjunto e } \\
\text { compartilhado em } \\
\text { todo o mundo }\end{array}$ & $\begin{array}{l}\text { Conhecimento } \\
\text { desenvolvido e } \\
\text { mantido em cada } \\
\text { unidade }\end{array}$ \\
\hline $\begin{array}{l}\text { Preocupação } \\
\text { básica }\end{array}$ & Eficiência & Aprendizado & $\begin{array}{l}\text { Eficiência, } \\
\text { aprendizado e } \\
\text { receptividade }\end{array}$ & Receptividade \\
\hline
\end{tabular}

Tabela 3: Padrões de Gestão de empresas com unidades em diversos países Fonte: Adaptado de Bartlett e Ghoshal, 1992

Podemos identificar claramente que os padrões global e multidoméstico da primeira classificação correspondem aos modelos global e multinacional da segunda. Analisados do ponto de vista de centralização e descentralização de decisões e atividades, podemos dizer que os modelos internacional e transnacional são intermediários ao global e ao multinacional, isto é, poderíamos colocar os modelos em um contínuo, onde global e multinacional seriam os extremos, e internacional e transnacional ocupariam posições intermediárias.

A classificação de Bartlett e Ghoshal é feita analisando a estratégia corporativa da empresa. De acordo com o grau de centralização, a atenção às peculiaridades dos

3 Para maiores detalhes sobre a forma transnacional, consulte a referência Bartlett e Ghoshal (1992). 
mercados locais, a configuração de suas competências e o foco básico da empresa, ela pode ser classificada em cada modelo. Se compararmos a classificação de arranjos organizacionais de Engenharia com as formas de gestão de empresas multinacionais da seção anterior, podemos encontrar a seguinte relação:

\begin{tabular}{|l|c|c|c|c|}
\hline Forma de Gestão & Global & Internacional & Transnacional & Multinacional \\
\hline $\begin{array}{l}\text { Tipo de arranjo } \\
\text { organizacional da } \\
\text { Engenharia }\end{array}$ & Centralizado & Centralizado & Distribuído & Descentralizado \\
\hline
\end{tabular}

Tabela 4: Comparação entre arranjos organizacionais da Engenharia e formas de gestão.

Podemos diferenciar o arranjo centralizado da Engenharia das empresas globais com o das empresas internacionais pelo grau de autonomia e conhecimento. Enquanto a empresa global mantém o conhecimento concentrado em sua matriz, a empresa internacional procurar disseminar esse conhecimento para suas unidades locais. Portanto em uma empresa internacional a Engenharia deve possuir uma capacidade técnica maior, que permita essa absorção do conhecimento, enquanto em uma empresa global a capacitação da Engenharia pode ser comparativamente menor.

$\mathrm{Na}$ empresa multinacional a Engenharia é descentralizada, pois o conhecimento é desenvolvido e mantido junto a cada unidade, possibilitando à empresa a capacidade de resposta desejada ao mercado local. Já a para a empresa transnacional, que busca simultaneamente integração de operações e contribuição das unidades locais, o arranjo distribuído para a Engenharia é mais apropriado, permitindo a existência de unidades especializadas (os centros de excelência), e a distribuição do conhecimento para todas as unidades. 


\section{ARRANJOS ORGANIZACIONAIS E A CAPACIDADE DE PROCESSAMENTO DE INFORMAÇÕES}

Organizações podem ser vistas e estudadas como sistemas de processamento de informações. Neste capítulo vamos trabalhar o conceito de fluxo de informações especificamente para o estudo dos arranjos organizacionais da Engenharia, pois informação e comunicação são freqüentemente associados na literatura ao desenvolvimento de produtos e processos, e a sua importância nesses processos é fortemente enfatizada. Porém, os conceitos desenvolvidos neste capítulo não são limitados somente à Engenharia, podendo ser utilizados para organizações em geral.

\section{ARRANJOS ORGANIZACIONAIS DA ENGENHARIA E OS FLUXOS DE INFORMAÇÕES}

O desenvolvimento de um produto e de seu processo de fabricação é uma atividade que demanda grande volume de transmissão e processamento de informações, devido ao alto grau de incerteza ao qual está submetido (Barczak e Wilemon, 1991). A importância da transmissão de informações dentro do processo de inovação tecnológica, desde o P\&D até a Engenharia foi estudada por diversos autores (para o P\&D, por exemplo: Allen, Lee e Tushman, 1980, Elmes e Wilemon, 1992, Iansiti, 1995. Para a Engenharia: Barczak e Wilemon, 1991, Clark e Fujimoto, 1991, Rosenthal e Takikonda, 1992, , Morelli, Eppinger e Gulati, 1995, Workman, 1995).

Clark e Fujimoto (1991, p.22) argumentam que a análise da organização a partir do ponto de vista do fluxo de informações fornece uma visão diferente da convencional, baseada no fluxo de materiais. De acordo com essa perspectiva (do fluxo de 
informações), o principal objetivo da organização é a comunicação com seus consumidores, e o produto por ela produzido passa a ser o veículo pelo qual as suas mensagens são entregues a eles (consumidores). Dessa forma, quando da utilização do produto, o consumidor recebe um conjunto de informações e os compara com suas expectativas e necessidades. O resultado dessa comparação determinará o grau de satisfação que ele terá com o uso do produto (Clark e Fujimoto, 1991).

O uso da perspectiva do fluxo de informações altera também a forma de se definir as atividades dentro da organização. Por exemplo o marketing passa a ser a atividade responsável pela comunicação na interface produtor/consumidor, pesquisando as expectativas dos consumidores e o seu nível de satisfação após o uso do produto, e os processos de manufatura são os responsáveis por incorporar fisicamente as informações desejadas às matérias-primas.

O desenvolvimento de produtos passa a ser o processo pelo qual a organização recebe as informações das oportunidades e necessidades do mercado (provenientes do marketing), e reúne a elas as informações das possibilidades técnicas que possui (provenientes de Pesquisa e Desenvolvimento), e as transforma em informações que possibilitem a produção comercial do produto pela Manufatura (idem, p.20). Esquematicamente esse fluxo de informações pode ser representado por:

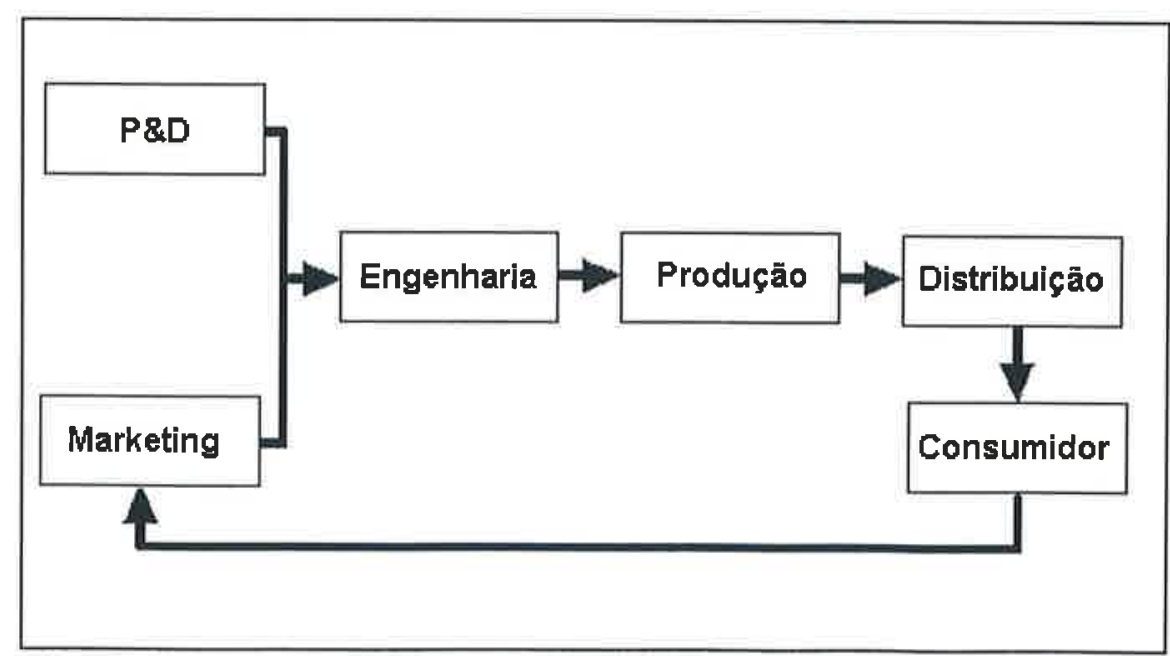

Figura 6 - Fluxo de Informações.

Fonte: adaptado de Clark e Fujimoto, 1991 


\section{A RELAÇÃO TECNOLOGIA - INFORMAÇÃO}

De um nível um pouco mais abstrato, podemos lembrar que a relação tecnologia e informação é muito forte pois "Tecnologia é uma ardente consumidora de informação" (Allen, 1977, p.2). A resolução de qualquer problema técnico se inicia com e depende de informações. Tecnologia consome informação, recebendo-a como sua "matériaprima" e, através da agregação de novas informações, transforma-a em outras.

A Engenharia normalmente recebe suas informações de entrada codificadas na forma de relatórios, especificações técnicas e estudos, e gera informações em outras formas (por exemplo desenhos, software ou peças piloto), que possibilitam a fabricação do produto. Essas informações são transmitidas para a Manufatura, que a partir delas produz seu produto.

Esse produto reflete as transformações sofridas pela informação inicial (proveniente do mercado) recebida pela Engenharia, durante o seu projeto e manufatura (idem, p.2). Assim, de um ponto de vista genérico, Tecnologia e informação têm uma relação muito forte, e o processo de inovação tecnológica, do qual a Engenharia é uma etapa, é um processo de transformação e transmissão de informações.

\section{A CAPACIDADE DE PROCESSAMENTO DE INFORMAÇÕES COMO FERRAMENTA DE ESTUDO DE ARRANJOS ORGANIZACIONAIS}

Como o conceito de fluxo de informações pode ser utilizado no estudo de organizações? Tushman e Nadler (1978) propõem o uso da capacidade de processamento de informações como conceito integrador do projeto organizacional de uma empresa bem-sucedida. Galbraith $(1973$, p.108) entende que as variações de 
estrutura organizacional encontradas entre as empresas são resultado das diferentes estratégias por elas utilizadas para se adaptarem aos requisitos internos de fluxo e processamento de informações.

Tushman e Nadler (1978) vêem as organizações basicamente como sistemas de processamento de informações que enfrentam incerteza. As premissas básicas utilizadas por eles nessa definição são:

1. Organizações são sistemas sociais abertos, sujeitos à incertezas relacionadas a seu negócio. Como elas dependem de informações do ambiente em que se encontram, e como esse ambiente é potencialmente instável, a organização deve ser capaz de acompanhar e lidar com a incerteza decorrente do ambiente.

Internamente, a organização deve ser capaz de resolver problemas oriundos das diferentes tarefas que realiza e coordenar as atividades exercidas pelas diferentes partes que a compõem. Em resumo, para seu funcionamento, a organização deve ser capaz de lidar tanto com incerteza criada pelo ambiente externo como com aquelas provenientes de suas funções internas.

2. Em decorrência da primeira premissa, as organizações podem ser vistas como sistemas de processamento de informações. Dada a existência de várias fontes de incerteza, uma as funções básicas da estrutura organizacional é criar a configuração mais apropriada para facilitar a efetiva aquisição, processamento e distribuição de informações.

3. A terceira premissa é que as organizações são compostas por conjuntos de unidades, pois à medida que crescem, existe a tendência à diferenciação e especialização. Essas unidades, apesar da especialização, são interdependentes e devem compartilhar de recursos limitados 
Tushman e Nadler (1978) contrapõem as necessidades de processamento com a efetiva capacidade de processamento de informações da organização e sugerem que a busca do correto balanço entre elas seja o critério utilizado para o projeto organizacional. Uma organização bem-sucedida é aquela que possui um arranjo organizacional cuja capacidade de processamento de informações é adequada às suas necessidades. Ou, esquematicamente:

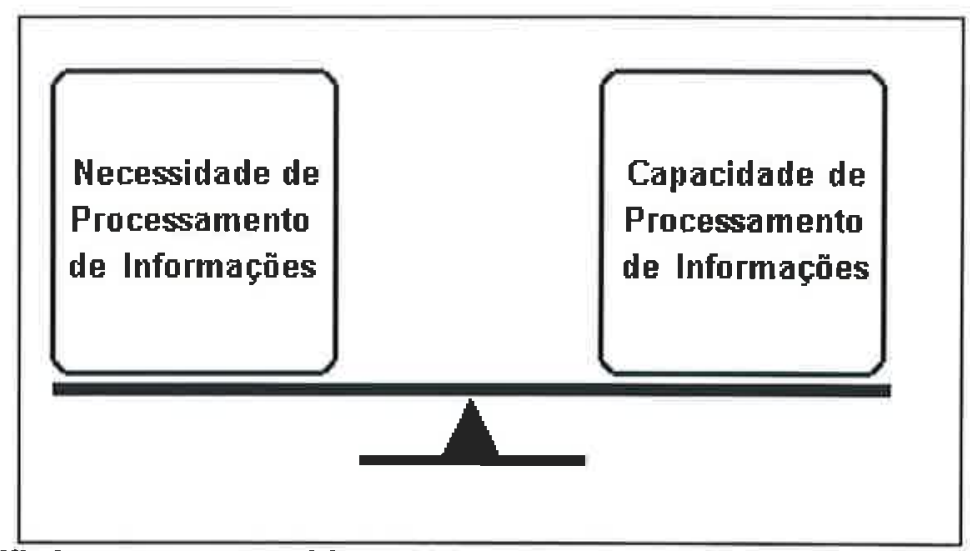

Figura 7 - Equilíbrio entre necessidade e capacidade de Processamento de Informaçōes.

Fonte: adaptado de Tushman e Nadler, 1978

\section{Fatores geradores de necessidade de informações}

A necessidade de processamento de informações de uma organização é função do grau de incerteza a que ela está submetida ${ }^{4}$. Quanto maior for a incerteza da tarefa, maior a quantidade de informações que precisa ser processada para a sua conclusão (Galbraith, 1973, p.4-5). Podemos identificar três fontes de incerteza para uma organização (Tushman e Nadler, 1978):

\footnotetext{
${ }^{4}$ Incerteza nessa caso é definida como a diferença entre a quantidade de informação necessária para a realização de uma tarefa e a quantidade de informação que a empresa possui para realizá-la (Galbraith, 1973, p.4-5).
} 


\section{As características da própria tarefa}

A complexidade da própria tarefa é uma fonte de incerteza. Essa complexidade depende da diversidade de saídas, isto é, do número de produtos e serviços oferecidos e do número de clientes que são atendidos. Também é função da quantidade de recursos disponíveis para a sua conclusão. Quanto mais parcos forem os recursos, maior a dificuldade em realizá-la. Dessa forma, o aumento dos recursos disponíveis é um fator de redução da incerteza.

Por exemplo o aumento dos prazos de execução de uma tarefa é uma forma de aumentar o recurso disponível (no caso o tempo) para a sua consecução. Esse aumento diminui a chance de que hajam atrasos, evitando a necessidade de consulta à hierarquia. A modificação e abrandamento de requisitos de projeto, outra forma de reduzir as exigências da tarefa, age da mesma forma, pois diminui a chance da ocorrência de um desvio pela dificuldade de atendê-los.

Além desses fatores externos à tarefa, o próprio nível de dificuldade interno da tarefa é uma fonte importante de incerteza, influenciando a quantidade de informações necessárias para a realização da tarefa (Galbraith, 1973, p.5).

\section{O ambiente em que a tarefa é realizada}

O ambiente externo à organização é uma fonte de incerteza, pois está fora do controle da organização e geralmente é instável, gerando necessidade de informações. Segundo Porter (1986), embora o ambiente em que a organização esteja inserido seja muito amplo, abrangendo forças sociais e econômicas, o seu aspecto principal é a intensidade da concorrência do seu setor industrial. As forças competitivas que determinam o grau de concorrência são:

- Rivalidade entre as empresas existentes no setor.

- Poder de negociação dos fornecedores. 
- Poder de negociação dos compradores.

- Ameaça de novos entrantes no setor.

- Ameaça de produtos ou serviços substitutos.

Em sua análise, Porter está preocupado especificamente com o aspecto econômico da empresa. O ambiente para ele tem dois componentes: o presente, representado pelos atuais concorrentes, fornecedores e clientes; e o potencial, onde se enquadram novos concorrentes e possíveis substitutos aos produtos da empresa. Além deles, Porter reconhece também a importância e influência da legislação e políticas governamentais na dinâmica competitiva entre empresas.

As forças competitivas básicas de Porter podem ser usadas no estudo da Engenharia expandindo-as para além da preocupação específica com a lucratividade. Por exemplo, no âmbito do relacionamento com os clientes (ou compradores como chama Porter), Clark e Fujimoto (1991, p.11) destacam o aspecto satisfação do cliente, definindo um critério denominado Complexidade da interface do produto com o cliente ou usuário.

Esse critério procura medir a expectativa do cliente em relação a um produto, isto é, a forma como o cliente avalia o produto. Quanto mais exigente for a avaliação, seja pelo uso de um grande número de critérios de performance, seja por uma alta importância de atributos subjetivos na avaliação ou pela necessidade de conseguir desempenho satisfatório e equilibrado em todos os aspectos, maior a complexidade da interface do produto com o cliente ou usuário. Dessa forma, o ambiente não é afetado apenas pelo poder de barganha do cliente, mas a maneira como ele avalia o produto interfere na competitividade da empresa.

$\mathrm{Na}$ verdade, Clark e Fujimoto definem uma forma de comparação entre diferentes setores industriais, usando o critério Complexidade da interface produto/usuário, discutido acima, e o critério Complexidade interna do produto, relativo à quantidade de componentes e etapas de produção distintas usadas em sua fabricação e seu grau de 
dificuldade tecnológica. Eles são dispostos ortogonalmente, formando uma matriz, que permite comparar setores industriais diferentes.

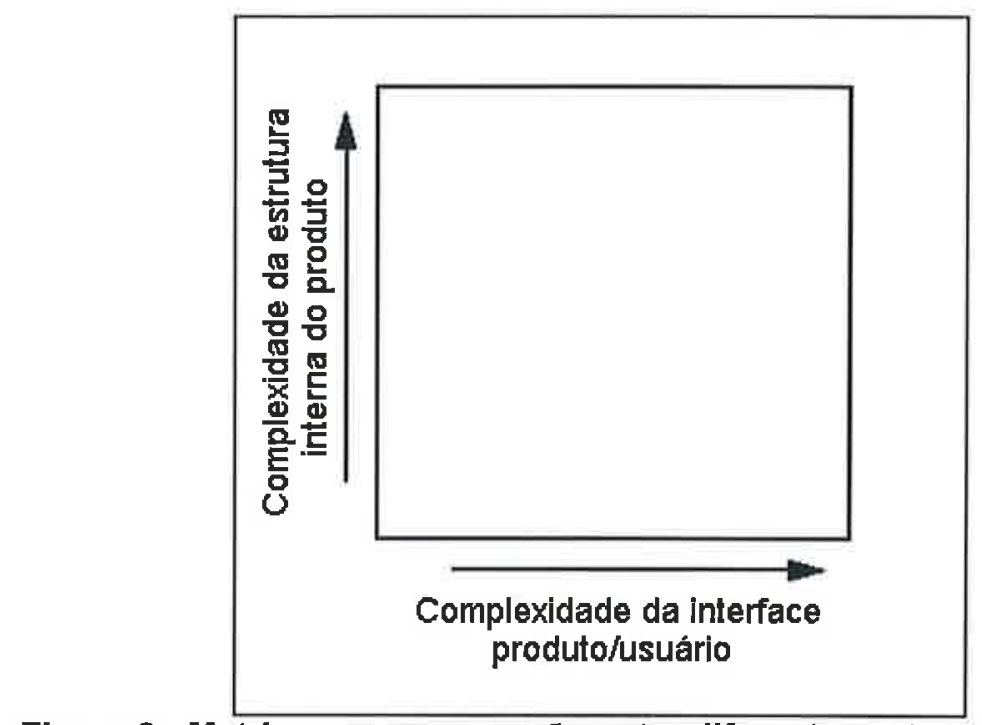

Figura 8: Matriz para comparação entre diferentes setores industriais Fonte: Adaptado de Clark e Fujimoto, 1991

\section{Grau de interdependência entre as diversas unidades dentro da organização.}

Quanto mais complexa for a interdependência entre as diversas unidades envolvidas na realização da tarefa, maior a necessidade de coordenação e planejamento conjunto. Thompson (1967), classifica a interdependência entre unidades em três níveis, em ordem crescente de complexidade: associação, seqüencial e reciproca ${ }^{5}$. Quanto mais complexo o tipo de interdependência, maior a necessidade de troca de informações.

\footnotetext{
${ }^{5} \mathrm{~A}$ interdependência por associação ocorre quando as funç̃̃es não têm interação direta entre si, mas contribuem independentemente para a realização da tarefa. A seqüencial ocorre quando, dadas duas funções, a saida de uma é a entrada para a outra. Finalmente a interdependência recíproca ocorre quando, dadas duas funções, a saída de uma é a entrada de outra, e vice-versa. Em outras palavras, a interdependência recíproca ocorre quando as funções realizam seus trabalhos simultaneamente e dependendo do resultado das outras.
} 
Uma forma de reduzir a necessidade de processamento de informações é exatamente diminuir o grau esse interdependência através da criação de "tarefas completas", onde cada grupo possui todos os recursos necessários para a conclusão de seu trabalho. Isso diminui a necessidade de processamento de informações por três razões:

- Diminui a variedade de saídas que o grupo deve atender, o que resulta em menor conflito e necessidade de determinação de prioridades.

- Diminui a divisão da tarefa em postos de trabalho, o que faz com que as ocorrências de sobrecarga ou capacidade ociosa sejam resolvidas dentro do próprio grupo, sem a necessidade de intervenção da hierarquia.

- Aproxima os pontos de tomada de decisão dos pontos de ação, pois esse mecanismo conduz a estruturas mais descentralizadas.

Esquematicamente podemos representar os três fatores geradores de incerteza, Complexidade da tarefa, Ambiente da organização e grau de interdependência entre unidades, responsáveis pela necessidade de processamento de informações de uma organização, da seguinte forma:

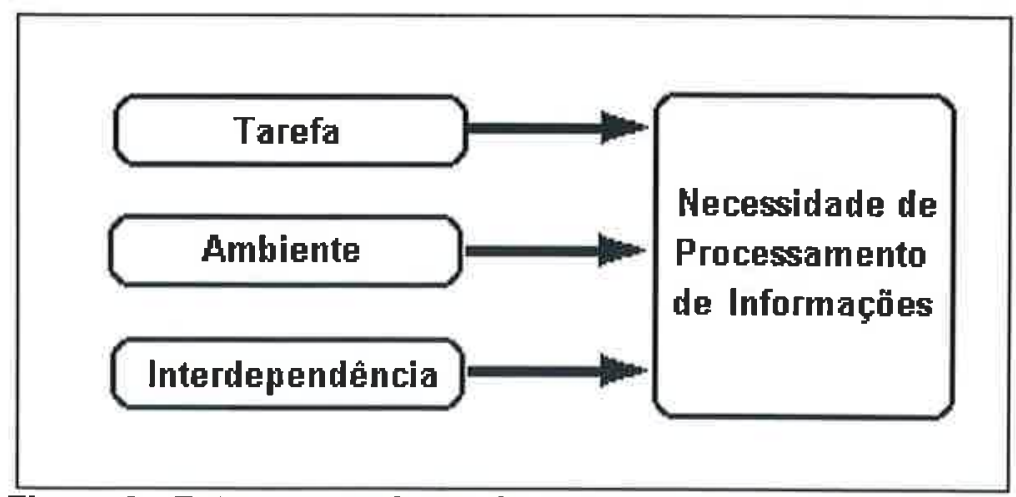

Figura 9 - Fatores geradores da necessidade de informações.

Fonte: adaptado de Tushman e Nadler, 1978 


\section{Fatores de influência na capacidade de processamento de informações}

Diferentes arranjos organizacionais possuem diferentes capacidades processamento de informações. Tushman e Nadler (1978) levantam dois aspectos do arranjo organizacional que influem diretamente na capacidade de processamento: a natureza da comunicação entre unidades (do ponto de vista orgânico/mecanicista de Burns e Stalker (1977)) e a forma de controle e coordenação utilizada entre as unidades.

\section{A natureza da comunicação entre unidades}

Uma unidade que tenha uma forma de comunicação mais orgânica, isto é, com incentivo à comunicação lateral, estrutura em rede para autoridade e comunicação e conhecimento disseminado pela organização, é mais apropriada para ambientes em mudança, onde haja constante surgimento de novos problemas e requisitos não previstos, ao contrário de unidades de natureza mecanicista, mais apropriadas a ambientes estáveis (Burns e Stalker, 1977, p.119-121). Um arranjo de natureza orgânica é mais apropriado para lidar com a incerteza.

Embora estruturas com comunicação mais orgânica sejam mais adequadas que as com comunicação mais mecanicista para lidar com grandes quantidades de incerteza, existem custos associados a essa característica. Estruturas orgânicas consomem mais tempo, esforço, energia e permitem um menor grau de controle gerencial. Dessa forma os benefícios do aumento de capacidade de lidar com incerteza devem ser balanceados com o aumento de custos, menor controle e possível aumento do tempo gasto na realização das tarefas (Tushman e Nadler, 1978). 


\section{Mecanismos de coordenação e controle}

Outro fator que define a capacidade de processamento de uma arranjo organizacional é o mecanismo de coordenação e controle existente entre as suas unidades. Em geral, quanto mais complexos, elaborados e abrangentes forem esses mecanismos, maior será a capacidade de processamento, embora os custos associados também cresçam (Tushman e Nadler, 1978). Os mecanismos básicos de coordenação e controle são (conforme Galbraith, 1973):

\section{Regras, programas e procedimentos}

É o método mais simples de coordenação. As regras eliminam a necessidade de futura comunicação entre as partes envolvidas na realização de uma determinada atividade. Enquanto as tarefas relativas a essa atividade possam ser antecipadas e regras possam ser estabelecidas com antecedência, a ação integrada das partes envolvidas é garantida sem a necessidade de comunicação.

As regras fazem o papel de hábitos dentro de uma organização. Porém, como no caso dos hábitos, o uso de regras é limitado às situações em que se possa antecipar os problemas a serem enfrentados e as respostas apropriadas a esses problemas possam ser identificadas e devidamente transformadas em regras, e procedimentos.

\section{Hierarquia}

Situações inusitadas para a organização, não cobertas pelas regras e procedimentos já estabelecidos, e portanto para as quais não existam ainda respostas prontas, podem muitas vezes afetar mais de uma unidade dentro da organização.

Para lidar com esse tipo de situações, recorre-se à hierarquia, pois os ocupantes dos cargos de gerência possuem informações e autonomia organizacional para a tomada de decisões não previstas pelas regras e procedimentos. Assim, quando 
eventos não antecipados surgem, são conduzidos aos gerentes, que possuem informações e autonomia para tomar a decisão.

É importante lembrar que a hierarquia é utilizada como complemento, e não no lugar das regras e procedimentos, pois ela é usada nas situações de exceção. As regras mantém a coordenação nas situações uniformes e repetitivas, enquanto as situações novas e imprevistas são levadas para cima na hierarquia. Esta combinação garante uma resposta coordenada para todas as situações que a empresa enfrenta.

Porém. se um número excessivo de novas situações acontece, a hierarquia se torna sobrecarregada, provocando sérios atrasos entre a transmissão do problema pelo canal hierárquico e a resposta à informação no sentido descendente.

\section{Planejamento conjunto}

Conforme a incerteza aumenta, por exemplo pelo surgimento de um grande número de situações não previstas pelas regras e procedimentos, a necessidade de transmissão de maiores volumes de informação entre os pontos de ação (isto é, aqueles que enfrentam a nova situação) e os de tomada de decisão (aqueles que podem indicar a solução a ser tomada) aumenta, sobrecarregando em muitos casos a hierarquia, provocando os atrasos já referidos.

Uma forma de evitar esse problema é trazer os pontos de tomada de decisão para junto dos pontos de ação, aumentando a autonomia dos que estão nos níveis mais baixos da organização. Se por um lado isso resolve o problema de transmissão de informações, por outro traz um problema adicional: como garantir que as pessoas envolvidas vão consistentemente tomar decisões que sejam corretas, garantindo a coordenação das diversas partes envolvidas?

Para enfrentar essa situação, as organizações mantém processos em que se estabelecem alvos e objetivos para as suas diversas partes, que cubram as 
interdependências básicas entre elas. Ou seja, um planejamento conjunto entre as partes da organização permite a elas a visão da direção que devem tomar e os limites entre si. O processo de estabelecimento de alvos e objetivos ajuda a coordenar as tarefas interdependentes e permite relativa autonomia de tomada de decisões nos níveis mais baixos .

Os três mecanismos básicos de coordenação são mostrados no esquema abaixo:

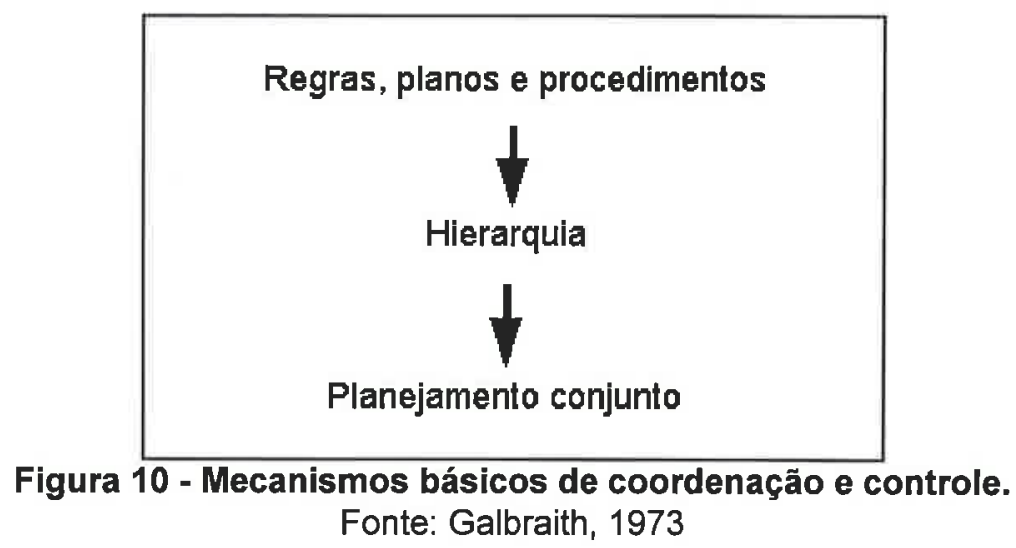

Porém, se a incerteza que a organização enfrenta cresce, o volume de informações a serem processadas pode exceder a capacidade de processamento de informações conseguido por esses três mecanismos. Neste caso a organização pode lançar mão de outros mecanismos para aumentar a sua capacidade de processamento de informações (Galbraith, 1973, p.14).

\section{Mecanismos adicionais para aumento da capacidade de processamento de informações}

A primeira forma direta de aumento da capacidade de processamento de informações é o uso de sistemas de informação verticais. Esse mecanismo aumenta a capacidade dos canais de comunicação existentes, cria novos canais e introduz novos mecanismos de tomada de decisão, utilizando a tecnologia da informação. 
O uso de sistemas de informação baseados em computadores, redes e bancos de dados compartilhados possibilita a disseminação rápida da informação, fazendo com que a necessidade de consulta à hierarquia diminua. Neste sentido o efeito do uso de um sistema de informação vertical é o mesmo dos mecanismos de redução da necessidade de processamento: menor necessidade de uso da hierarquia.

Outra estratégia para aumentar a capacidade de processamento é a criação de relações laterais. Um exemplo dessa estratégia é o contato direto entre duas pessoas que enfrentam o mesmo problema. A discussão, acordo e definição de ações para a resolução do problema pode ser tomada sem a necessidade de consulta a níveis superiores da hierarquia, diminuindo a sobrecarga de transmissão de informações.

Essa estratégia também desloque o ponto de tomada de decisões para baixo, fazendo com que, no lugar de preparar e enviar informações para cima pelo canal hierárquico, a decisão seja tomada no nível onde ela existe, ela não introduz mudanças na estrutura organizacional, como no caso dos grupos de tarefas completas. (Galbraith, 1973, p.18). O esquema completo, mostrando os mecanismos básicos e adicionais de coordenação e controle é ilustrado a seguir:

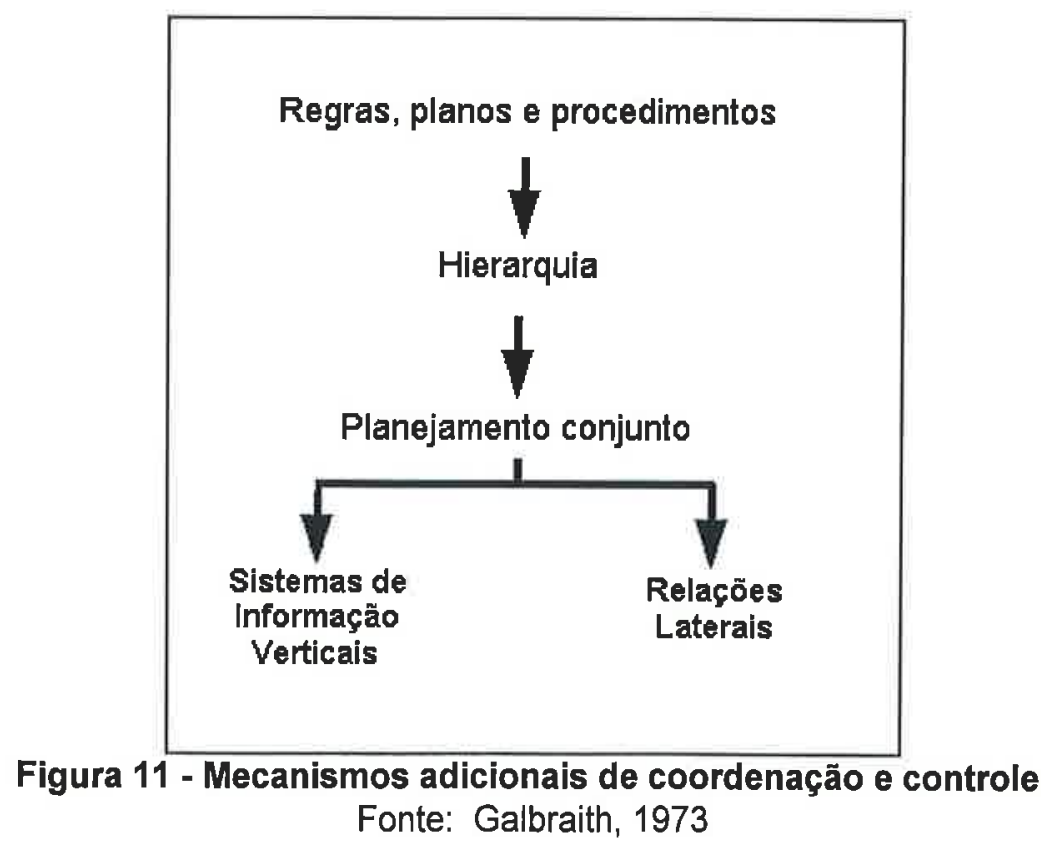


Esquematicamente os fatores de influência na capacidade de processamento de informações, Natureza do arranjo organizacional da unidade e forma de coordenação e controle utilizada entre unidades, podem ser representados por:

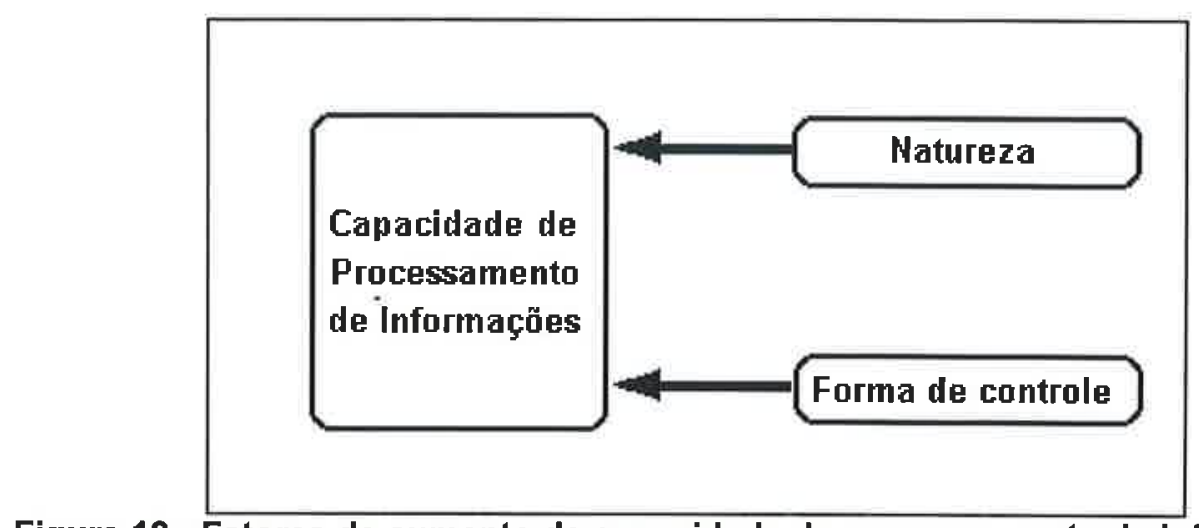

Figura 12 - Fatores de aumento da capacidade de processamento de informações.

Fonte: Tushman e Nadler, 1978

Reunindo os esquemas de necessidade e capacidade de processamento, ilustrados nas figuras 9 e 12, podemos detalhar melhor o esquema da figura 8, proposto por Tushman e Nadler (1978):

Figura 13 - Equilíbrio entre necessidade e capacidade de processamento de informações e seus fatores geradores.

Fonte: Tushman e Nadler, 1978 


\section{OS ARRANJOS ENTRE UNIDADES DE ENGENHARIA E A CAPACIDADE DE PROCESSAMENTO DE INFORMAÇÕES}

$O$ esquema da figura 13 sugere que deve haver equilíbrio entre a complexidade da tarefa, o ambiente da empresa e o tipo de interdependência entre unidades, com a natureza da comunicação utilizada no arranjo organizacional e sua forma de coordenação e controle. Ele nos dá um ponto de partida para discutirmos os arranjos organizacionais entre unidades de Engenharia.

A estratégia corporativa de empresas com múltiplas unidades define: o grau de centralização de suas atividades principais, a autonomia de cada unidade, a forma como as suas competências básicas são distribuídas dentro da organização e o modo de desenvolvimento e difusão do conhecimento entre as unidades locais. A partir dessa estratégia, os departamentos de Engenharia podem ser configurados de forma centralizada, distribuída ou descentralizada. Cada uma dessas configurações tem aspectos positivos e negativos, conforme já discutimos no capítulo anterior.

A hipótese do equilíbrio entre a necessidade e capacidade de processamento de informações permite discutir se o arranjo organizacional adotado por uma empresa satisfaz essa condição. Ele interfere diretamente no tipo de interdependência entre as unidades (se associação, seqüencial ou recíproco), , na natureza mecanicista ou orgânica da comunicação das unidades e nas formas de controle e coordenação utilizadas entre elas.

Por exemplo, empresas que optam por uma estratégia do tipo global têm alto grau de concentração das atividades no órgão central de Engenharia, responsável pelo desenvolvimento de produtos e pela disseminação desse conhecimento para outras unidades. Nesse caso, o grau de interdependência entre unidades de Engenharia locais é baixo, pois o canal de comunicação mais importante é com o órgão central, e a tarefa 
das unidades locais, devido à centralização, é simples. Podemos esperar então que sejam utilizadas formas de coordenação mais simples entre as unidades.

No extremo oposto, empresas que optam por uma estratégia multinacional têm as tarefas das unidades locais de Engenharia complexas, pois elas são as responsáveis pelo desenvolvimento de seus projetos. Por esse mesmo motivo, o conhecimento está disperso entre as unidades. Se uma unidade necessitar do conhecimento que outra possui, deve procurar transferi-lo para si, o que faz com que o grau de interdependência entre elas seja complexo. Nesse caso a forma de coordenação utilizada entre elas deve ser mais complexa.

Portanto, se a hipótese de que empresas bem sucedidas têm arranjos organizacionais onde a necessidade de processamento de informações é equilibrada pela correspondente capacidade de processamento for verificada, então podemos compreender melhor como as empresas estão estruturando os seus departamentos de Engenharia. Isso nos remete de volta à nossa pergunta inicial: "Como as empresas com múltiplos departamentos de Engenharia estão se estruturando para competir no mercado globalizado?". Para respondê-la, podemos elaborar proposições de pesquisa mais específicas, utilizando o conceito de equilíbrio capacidade/necessidade de processamento de informações discutido. No próximo capítulo vamos detalhar essas proposições. 


\section{METODOLOGIA E FORMULAÇÃO DAS PERGUNTAS DE PESQUISA}

\section{DEFINIÇÃO DA PERGUNTA DE PESQUISA}

A pergunta de pesquisa inicial deste trabalho é de caráter exploratório. Procuramos com ela entender a forma como a Engenharia está sendo estruturada no ambiente atual. Foi formulada da seguinte maneira:

"Como as empresas com múltiplos departamentos de Engenharia estão se estruturando para competir no mercado globalizado?"

Usando a hipótese do equilíbrio entre necessidade e capacidade de processamento de informações, podemos afirmar por exemplo que empresas que tenham alta necessidade de informações em seus setores de Engenharia exigem arranjos organizacionais com alta capacidade de processamento. Ou, usando um raciocínio inverso, afirmar que empresas que possuem arranjos organizacionais com menor capacidade de processamento em seus setores de Engenharia pedem redução da necessidade de processamento de informações.

Se procurarmos determinar a necessidade de processamento de informações entre os departamentos de Engenharia de uma empresa, através análise da complexidade de sua tarefa, do seu ambiente competitivo e do grau de interdependência entre as unidades de Engenharia, podemos fazer a comparação com a capacidade de processamento correspondente ao seu arranjo organizacional, pela observação da natureza da organização e dos mecanismos de coordenação e controle utilizados. Essa comparação permite verificar a hipótese do equilíbrio. Uma proposição que verifica essa hipótese pode ser assim formulada: 
Proposição (1a)

"Uma empresa que opte por ter tarefas mais complexas em suas unidades de Engenharia locais e um maior grau de interdependência entre elas tem um arranjo organizacional com uma forma de coordenação mais complexa, com comunicação de natureza orgânica."

A verificação dessa proposição impõe a necessidade definir como cada uma das variáveis envolvidas será avaliada, isto é, por exemplo, estabelecer o que é uma tarefa ou uma forma de coordenação complexa. Temos portanto a necessidade de estabelecer formas de medir cada uma das variáveis envolvidas.

\section{MEDIÇÃO DAS VARIÁVEIS DA PROPOSIÇÃO DE PESQUISA}

O esquema da figura 14 nos deixa com cinco variáveis de estudo: (1) a tarefa das unidades de Engenharia, (2) o seu ambiente competitivo, (3) o grau de interdependência entre unidades, (4) natureza da comunicação entre variáveis e (5) a forma de coordenação e controle existente entre elas. Vamos agora discutir em detalhe como podemos medir cada uma dessas variáveis.

O grau de complexidade da tarefa da Engenharia local será medido recorrendo-se à descrição de atividades feita no segundo capítulo, ilustrado pela figura 2. Vamos considerar que quanto maior o número de atividades realizadas pelas unidades de Engenharia locais, maior é o grau de complexidade de sua tarefa. De maneira inversa, quanto menor o número de atividades realizadas pelas unidades de Engenharia locais, menor é o grau de complexidade da tarefa. 
Para a avaliação do ambiente da empresa, vamos reduzir as três primeiras forças competitivas de Porter para apenas uma: poder de negociação dos compradores ${ }^{6}$. Essa simplificação equivale à suposição de que todas as empresas que iremos estudar têm concorrentes igualmente competentes e que tenham também fornecedores independentes, isto é, com autonomia em relação às empresas estudadas. As suposições parecem razoáveis desde que não estudemos empresas de setores excessivamente oligopolizados.

Usaremos em nosso estudo o conceito ampliado de Clark e Fujimoto: grau de complexidade da interface produto/usuário, conforme já discutido no capítulo anterior, avaliando os seguintes pontos: número de critérios de performance utilizados na avaliação, importância de atributos subjetivos, necessidade de conseguir desempenho satisfatório e equilibrado em todos os requisitos.

O grau de interdependência entre unidades será medido usando-se a classificação de Thompson (1967, p.54). Como já foi discutido no capítulo anterior, sua classificação envolve as seguintes formas: interdependência por associação, seqüencial e recíproca. As três formas de interdependência são de grau de complexidade de coordenação crescente, pois têm uma maior influência de fatores contingenciais.

$\mathrm{Na}$ associação, cada unidade pode prosseguir seu trabalho de forma independente, mesmo que hajam dificuldades em uma das unidades. Já na interdependência seqüencial, cada unidade precisa se reajustar caso hajam dificuldades nas unidades à sua montante. Existe portanto sempre uma possível necessidade de ajuste e coordenação das unidades. No caso da interdependência recíproca, cada modificação em qualquer unidade exige ajustes em todas as outras unidades (Thompson, 1967, p.55).

\footnotetext{
6 Consideramos que as cinco forças competitivas de Porter são divididas em três "presentes": concorrentes, fornecedores e clientes, e duas "potenciais": novos concorrentes e produtos alternativos. Como a nossa análise se limita à situação corrente das empresas, iniciamos a análise partindo somente das três forças "presentes".
} 
Os tipos de interdependência não são mutuamente exclusivos. Todas as organizações possuem interdependência por associação. Organizações mais complexas possuem interdependência por associação e seqüencial, e as mais complexas os três níveis: associação, seqüencial e recíproca. Se uma organização possui interdependência seqüencial, automaticamente ela possui a associação, e se ela possui a recíproca, então ela também possui as outras duas formas (idem, p.55). Essa relação pode ser representada pelo seguinte diagrama, onde cada forma mais complexa contém as mais simples:

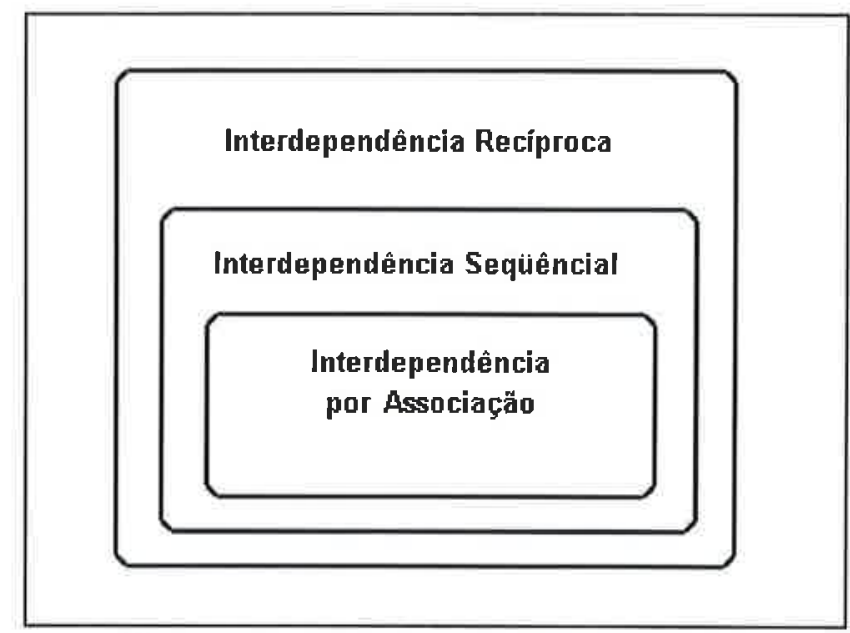

Figura 14- Tipos de Interdependência.

Fonte: 'Baseado em Thompson, 1967

A natureza da comunicação entre unidades será avaliada como orgânica se houver: estrutura em rede para controle, autoridade e comunicação (vamos considerar que quanto mais descentralizado for o arranjo organizacional, maior será a sua característica orgânica), conhecimento específico sobre as tarefas localizado nas unidades locais e ênfase na comunicação lateral. Se por outro lado houver predominância do uso da hierarquia para comunicação e controle e conhecimento centralizado em uma unidade, a natureza da comunicação será considerada mecanicista.

Finalmente, para avaliar a complexidade da forma de coordenação e controle do arranjo organizacional, vamos utilizar a escala de Galbraith (1973), representada na figura 11. As formas de coordenação e controle propostas formam um contínuo, de crescente 
grau de custo, complexidade e capacidade de processamento de informações. O grau de complexidade aumenta conforme avançamos de Regras, Planos e Procedimentos para Planejamento conjunto. Após esses mecanismos, existem ainda duas possibilidades que podem ser adotadas em conjunto ou separadamente: Sistemas de Informação Verticais e Relações Laterais. A primeira possibilidade é mais adequada para informações quantificáveis, enquanto a segunda é mais apropriada para informações de caráter informal, não quantificáveis (Tushman e Nadler, 1978)

Dessa forma podemos medir as variáveis de nossa proposição, medindo a complexidade da tarefa, o grau de interdependência entre unidades e verificando a natureza da comunicação e o mecanismo de coordenação e controle utilizado. Porém existe um problema adicional: Como estabelecer uma escala absoluta de medida de forma a comparar a necessidade de processamento advinda da tarefa e da interdependência com a capacidade de processamento de seu arranjo organizacional?

Vamos neste estudo contornar, e não superar essa dificuldade. Para evitar esse problema, podemos comparar empresas, analisando as características geradoras de necessidade de informação de cada uma, para em seguida comparar os arranjos organizacionais e a sua correspondente capacidade de processamento. A proposição de pesquisa correspondente fica então modificada de seguinte forma:

Proposição (1b)

"Empresas que tenham tarefas mais complexas em suas unidades de Engenharia locais, ambientes mais complexos e um maior grau de interdependência entre elas têm arranjos organizacionais com uma forma de coordenação mais complexa e natureza da comunicação mais orgânica do que empresas com tarefas, ambiente e interdependência mais simples." 


\section{MÉTODO DE PESQUISA A SER EMPREGADO}

Os aspectos que vamos observar nas empresas a serem estudadas são: a complexidade da tarefa da unidade local, o grau de interdependência entre as unidades, o grau de complexidade da interface com o usuário, a natureza da comunicação e a forma de coordenação entre as unidades. Para isso a observação e compreensão do ponto de vista das empresas pesquisadas é de fundamental importância para a obtenção de dados confiáveis e sua correta interpretação. Isto nos conduz ao planejamento de uma pesquisa de enfoque qualitativo.

A escolha do enfoque qualitativo entretanto coloca duas dificuldades: em primeiro lugar, a responsabilidade do pesquisador aumenta na medida em que a qualidade dos dados obtidos depende fortemente de sua habilidade e percepção (o que Glaser e Strauss (1967, p.46) chamam de sensibilidade teórica do pesquisador). Algumas características que um pesquisador deve possuir são (Yin 1994, p.56):

- Ser capaz de fazer boas perguntas.

- Ser um bom ouvinte, sem preconceitos.

- Ser flexível e com boa capacidade de adaptação.

- Ter uma clara visão dos assuntos que estão sendo estudados.

- Não ser tendencioso por causa de noções pré-concebidas.

Em segundo lugar, a comparação dos dados pode ser mais problemática, pois a chance de se encontrar diversas abordagens diferentes sobre o mesmo assunto, e que sejam de difícil comparação, aumenta. Porém, como as variáveis foram discutidas quando da formulação da proposição de pesquisa, não esperamos encontrar dificuldades neste aspecto.

De acordo com a formulação de nossa pergunta de pesquisa, o método mais adequado é o Estudo de Caso. Segundo Yin (1994, p.4), além do tipo de pergunta de pesquisa, são condições básicas na escolha do método: o grau de controle do pesquisador sobre os eventos estudados e o grau de foco sobre eventos históricos ou contemporâneos. Em 
nosso caso não existe controle sobre os eventos estudados e o foco é sobre assuntos contemporâneos, o que corrobora a escolha do estudo de caso. A unidade de análise será o departamento de Engenharia local, seu arranjo organizacional e suas relações com os outros departamentos de Engenharia.

O instrumento de coleta de dados principal utilizado foi a entrevista semi-estruturada pois para se atingir a compreensão desejada da situação de cada empresa, o contato do pesquisador com as empresas é fundamental. Por outro lado, o fato que cada empresa tenha estrutura organizacional diferente exige flexibilidade do instrumento de coleta, de forma a adaptar-se à realidade de cada uma. A entrevista semi-estruturada permite o contato do pesquisador com as empresas pesquisadas e a possibilidade de adaptação caso a realidade encontrada seja distinta daquela esperada.

A escolha das empresas a serem estudadas foi feita usando o conceito da amostragem teórica, de Glaser e Strauss (1967). Diferentemente do que ocorre em uma amostragem estatística, onde se procura uma amostra aleatória que seja representativa da população, na amostragem teórica o critério básico para a seleção de unidades de estudo é sua relevância teórica, ou seja, a sua contribuição para o desenvolvimento do assunto. Dessa forma, procuramos escolher duas empresas que representassem dois casos polares, com características que permitam sua classificação clara e imediata em uma das categorias definidas na tabela a seguir. A comparação entre duas empresas com essas características permite verificar se é possível verificar a proposição (1b). 


\begin{tabular}{|c|c|c|}
\hline & $\begin{array}{c}\text { Polo A } \\
\text { Engenharia Local Complexa }\end{array}$ & $\begin{array}{c}\text { Polo B } \\
\text { Engenharia Local Simples }\end{array}$ \\
\hline $\begin{array}{l}\text { Número de unidades de } \\
\text { Engenharia locais }\end{array}$ & Múltiplo & Múltiplo \\
\hline Tarefa da Engenharia local & $\begin{array}{l}\text { Complexa } \\
\text { Realização de todas as } \\
\text { atividades da figura } 2\end{array}$ & $\begin{array}{c}\text { Simples } \\
\text { Realização do mínimo de } \\
\text { atividades possiveis da figura } \\
2\end{array}$ \\
\hline Ambiente & $\begin{array}{l}\text { Interface com o usuário mais } \\
\text { complexa }\end{array}$ & $\begin{array}{l}\text { Interface com o usuário mais } \\
\text { simples }\end{array}$ \\
\hline Natureza da comunicação & Orgânica & Mecanicista \\
\hline $\begin{array}{c}\text { Grau de interdependência } \\
\text { entre unidades de Engenharia } \\
\text { local }\end{array}$ & Complexa (Reciproca) & Simples (Associação) \\
\hline
\end{tabular}

Tabela 5 - Tipos de empresas polares a serem pesquisadas

As empresas escolhidas para os estudos de caso são conhecidas mundialmente, e reconhecidas como líderes em seus setores industriais. Atuam em setores que não podem ser classificados como oligopolizados, o que preenche a premissa assumida para a simplificação da análise do ambiente competitivo. Ambas são tema de diversos estudos de caso e citações freqüentes em livros de grande circulação nas áreas de administração e engenharia.

A empresa $\mathrm{A}$, de história centenária, tem sido muito estudada devido ao seu arranjo organizacional, considerado ousado e inovador. A empresa B é citação freqüente em publicações sobre desenvolvimento de produtos e engenharia. As duas empresas possuem unidades espalhadas ao redor do mundo, preenchendo o primeiro requisito requerido, múltiplas unidades de Engenharia, e estão presentes no Brasil há diversos anos, possuindo Manufatura local.

Foram realizadas as seguintes entrevistas: na empresa $\mathrm{A}$ - o diretor responsável pelo marketing corporativo da unidade, um gerente de produto $\mathrm{e} o$ gerente de 
engenharia. Cada uma das entrevistas durou cerca de 1,5hs. Na empresa B foi entrevistado o gerente de engenharia de manufatura ( 2 vezes), em entrevistas que tiveram duração de aproximadamente 1,5hs. Foi feita uma entrevista com um gerente comercial utilizando-se o recurso do correio eletrônico (e-mail).

Além das entrevistas, forma utilizados materiais de outras fontes: A empresa A forneceu material de divulgação e uma série de artigos de revistas nacionais $\mathrm{e}$ internacionais sobre a o seu arranjo organizacional. A página web da empresa também foi acessada. Na empresa $\mathrm{B}$, foi conseguida a cópia de uma entrevista escrita com o gerente geral de uma unidade da empresa no exterior, parte de outra pesquisa na mesma empresa, e que trata de diversos pontos de interesse comum. A página web da empresa também forneceu dados para o estudo de caso. 


\section{Resultados E discussão}

\section{Estudo de CAso - Empresa A}

A empresa A é uma multinacional, com presença em mais de 140 países, com cerca de 1300 empresas. No Brasil, está presente desde 1912, possuindo 5 fábricas, com mais de 3 mil funcionários, e atua fortemente no mercado de exportação para Europa, Ásia, Oriente Médio e Américas. É o resultado da fusão de duas grandes empresas européias, e tem se caracterizado pela inovação em sua visão estratégica e estrutura organizacional.

Possuindo unidades espalhadas ao redor do mundo, produz diversos tipos de produtos, atuando basicamente no ramo de geração e transmissão de energia. Emprega uma forma organizacional fortemente descentralizada, com o desmembramento da empresa em mais de 5000 centros de custo, cada um atuando como uma unidade de negócios autônoma, responsável por sua própria lucratividade e pelo seu sucesso ou fracasso.

A empresa emprega alguns conceitos básicos para definir a sua estrutura organizacional: em primeiro lugar a chamada multidomesticidade (cada empresa é uma companhia doméstica, que atua no mercado local, sendo ao mesmo tempo parte da rede global). A preocupação com o mercado local se justifica pelo seu tipo de produto, basicamente sob encomenda. Por esse motivo, existe uma grande ênfase na proximidade, conhecimento e atendimento das necessidades dos clientes (o chamado costumer focus). Em segundo lugar, outro conceito utilizado é o da descentralização, isto é, as decisões normalmente são tomadas a nível do país ou da unidade de negócios.

No âmbito mundial a empresa possui uma estrutura matricial, onde se cruzam a coordenação das empresas por regiões do mundo, com a coordenação por área de 
negócios. Existem em princípio áreas pré-determinadas de atuação de cada empresa, definidas pela região geográfica (por exemplo no Brasil atua a unidade brasileira), mas em certos casos mesmo essa divisão pode ser deixada de lado. Por exemplo, em alguns casos o órgão central de coordenação da área de negócios ao qual o projeto pertence define qual unidade deve participar na concorrência, baseada em critérios técnicos e comerciais.

Além disso a coordenação das regiões faz a formulação das estratégias e a coordenação das atividades locais de cada empresa, com foco no desenvolvimento do mercado local, enquanto a coordenação das áreas de negócios preocupa-se com a formulação das estratégias globais, o desenvolvimento de produtos, e a alocação de produtos e mercados. Dessa forma a empresa procura atingir o que chama de "Escala global e tecnologia classe mundial com raízes profundas na comunidade local".

São apontados como pontos fortes da forma organizacional adotada: flexibilidade, pois as decisões são tomadas muito próximas aos locais de ação, agilidade para atender às demandas do mercado e conhecimento profundo do mercado local. Como pontos fracos são citados: a possibilidade da não otimização de recursos, e a necessidade de alto fluxo de informações, pois a ligação que une a rede de empresas são as comunicações. Devido ao tamanho da empresa e sua política de descentralização, a comunicação tornou-se cada vez mais complexa; sendo fato reconhecido dentro da empresa a dificuldade em alcançar todos os funcionários ao redor do globo.

Um exemplo desse reconhecimento pode ser ilustrado por esta declaração do principal executivo responsável pela fusão das duas empresas: "Uma preocupação chave para mim é: como alcançar uma boa comunicação e estabelecer comunicação em duas vias? Eu costumo dizer que 5 a 10\% da gestão é pensamento estratégico, e 90 a 95\% é execução. E uma grande parcela da execução é comunicação, motivando as pessoas e fazendo-as comprar a idéia, tornando-se comprometidas." 
A empresa investe fortemente em pesquisa e desenvolvimento, tendo destinado no ano de 1996 cerca de 10\% do seu faturamento. Dentro desse esforço, realiza algumas atividades de pesquisa pura, porém concentra a maior parte dos recursos em pesquisa aplicada e engenharia. A pesquisa aplicada é realizada de forma distribuída, coordenada pela área de negócios respectiva e concentrada em centros de pesquisa e desenvolvimento sediados em três países europeus. A Engenharia de aplicação é local, com departamentos de Engenharia localizados em cada unidade produtiva. $O$ desenvolvimento de uma tecnologia dentro de uma unidade é função de oportunidade, não há um planejamento rigoroso centralizado que defina as atividades de cada unidade.

Pela existência de diversos departamentos de Engenharia, a empresa possui uma política de concorrência interna para a realização dos seus trabalhos, procurando o menor custo e a maior competência técnica para o seu produto. Segundo um dos entrevistados, " $A$ empresa é um grande shopping center", isto é, uma unidade pode procurar a tecnologia e a competência que necessita em qualquer outra unidade ao redor do mundo.

Dentro desse esquema, é fundamental que todas as unidades tenham conhecimento das competências, dos trabalhos e experiências acumuladas por todas as outras unidades, para que possam recorrer a esse conhecimento quanto necessário. A administração mundial da área de negócios, localizada na sede da empresa, possui um pequeno grupo que coordena as atividades técnicas de todas as unidades. Ela realiza duas iniciativas para a divulgação interna das atividades técnicas:

- Programas que visam uniformizar a tecnologia utilizada dentro do grupo. O objetivo desses programas é estabelecer um padrão uniforme de atuação e de projetos, com a edição de manuais que compilem a experiência de todas as unidades do grupo. Existe também um programa, em fase de implantação, que incentiva a reutilização de soluções já encontradas por uma unidade, disponibilizando-as para qualquer unidade em todo o mundo. O programa está sendo iniciado para a manufatura e deve ser estendido também para a Engenharia. 
- Quatro reuniões anuais entre as maiores unidades do grupo, onde se discute as direções a serem tomadas e os projetos realizados. Além dessas reuniões são realizadas outras duas, também anuais, com os gerentes de todas as unidades do grupo, onde se trocam experiências e conhecimentos, e se promove o contato entre os engenheiros de todas as unidades, facilitando futuros contatos.

O alto custo dessas soluções é reconhecido pela própria organização. Também é reconhecido o papel fundamental do grupo de coordenação técnica da unidade de negócios. Embora ele não realize atividades técnicas propriamente ditas, o seu papel como facilitador do processo de difusão de informações e como árbitro nas decisões de disputa de negócios entre unidades, comuns no sistema adotado pela empresa, é considerado muito importante.

Dentro da unidade brasileira, a Engenharia é organizada na forma de grupos multidisciplinares, que assumem a o projeto de um cliente do começo ao final, no lugar da tradicional estrutura funcional com especialistas. Os trabalhos são alocados para cada grupo conforme a experiência e conhecimento de cada um deles. A avaliação do trabalhos de cada grupo é feita pelo número de não-conformidades, traduzido pelo custo do projeto.

\section{Um exemplo de aplicação: Projeto e construção de equipamento para geração de energia.}

O equipamento principal do projeto utiliza uma tecnologia nova para a unidade brasileira. Em contato com o grupo de coordenação técnica e pelo conhecimento advindo dos encontros anuais, a Engenharia brasileira tinha conhecimento que essa tecnologia fora utilizada com sucesso por uma unidade européia em um projeto nos E.U.A . Após contatos comerciais, o projeto foi adquirido da unidade européia. No 
início do projeto alguns engenheiros brasileiros foram enviados à unidade européia para acompanhar a realização do projeto e acompanhar a fabricação de equipamentos semelhantes.

Em seguida os desenhos vieram da Europa, e foram "tropicalizados" pela Engenharia local, isto é, os métodos fabricação e os materiais foram adaptados para o mercado e condições internas. Durante a fase de adaptação do projeto e construção, utilizou-se intensamente os meios de comunicação convencionais, como telefone e fax. A empresa também faz uso intensivo de um software de transmissão e compartilhamento de informações, tanto para assuntos técnicos como para administrativos.

Todo o processo de fabricação está sendo acompanhado pela unidade européia, responsável pelo projeto. Na fase final de construção, alguns engenheiros da unidade européia acompanharão o término da fabricação, a montagem e posta-em-marcha do equipamento.

\section{ESTUdo de CASO - EMPRESA B}

A empresa foi criada no final da década de 30, produzindo inicialmente equipamentos de teste e medição. Durante seus primeiros anos produziu principalmente equipamentos eletrônicos de medição e controle. A partir do final da década de 50 iniciou um processo de internacionalização, abrindo plantas na Ásia e Europa. Também por essa época diversificou sua linha de produtos, produzindo equipamentos para a área médica e química analítica. A partir de meados da década de 60 iniciou uma linha de produtos voltada para o processamento e transmissão de dados, que hoje representam a maior parcela de seu faturamento mundial.

A empresa está no país desde 1967. Recentemente (cerca de 2 anos) mudou sua estratégia de negócios. Até então ela era associada a uma empresa brasileira, e 
concentrava sua produção em um produto eletrônico relativamente barato, que exigia produção automatizada e alto volume. Com a dissolução dessa associação, a empresa está passando por uma fase de consolidação, após a retomada do controle total dos seus negócios no Brasil.

A empresa divide os seus negócios no mundo em quatro grandes regiões: EUA (incluindo Canadá), América Latina, Europa/África e Ásia. A maior planta e a coordenação das operações na região América Latina se encontra no México. Há cerca de um ano, dentro do processo de restruturação, a empresa montou uma operação de distribuição no Brasil, sediada em São Paulo.

A estrutura internacional que a empresa adota é matricial (apesar disso não ser explicitamente declarado nas entrevistas), onde se cruzam a coordenação de operações por regiões com uma coordenação por linha de produtos. Os resultados do negócio são consolidados por região, enquanto as pesquisas e desenvolvimento tecnológico são orientados e realizados pela coordenação de cada linha de produto.

Segundo um de seus diretores, do ponto de vista das vendas a empresa é uma multinacional, com a apuração de resultados sendo realizada utilizando-se a divisão do mercado mundial já citada. Porém analisada do ponto de vista do fluxo de inovação tecnológica, a empresa é global, isto é, cada linha de produtos conta com um laboratório de pesquisa e um centro de excelência (responsável pelo projeto de novos produtos) único, que realiza os desenvolvimentos para todas as unidades. A estrutura organizacional administrativa se parece muito com a da empresa A.

No Brasil a empresa atende basicamente o mercado corporativo, atuando muito pouco no mercado "de varejo" de computadores pessoais (a linha de impressoras, que atende esse mercado, é produzida fora no exterior e somente distribuída no país). Por esse motivo, sua produção é feita sob encomenda, pois cada cliente em geral especifica as características do produto, escolhendo dentro de um número limitado de opções (Esse tipo de mercado exige flexibilidade de configuração e rapidez de entrega) Trabalha com 
plataformas padronizadas a nível mundial, e uma linha de acessórios definida, que permite certa flexibilidade de configurações.

A empresa possui hoje cerca de 60 unidades ao redor do mundo. Em cada local, a estratégia é começar pequeno e ir crescendo gradualmente, passando por estágios como distribuidor, agente comercial, distribuidor com montagem final, fabricante local, de acordo com o desempenho obtido pela unidade. A operação de produção montada no Brasil é de porte pequeno, constituída de distribuição e montagem final. Possui as seguintes divisões: Manufatura, Logística (que inclui terceirização), Planejamento e Compras (incluindo todas as compras e importações) e Negócios (processamento de pedidos, gestão de contratos). As instalações produtivas são de propriedade da empresa, mas a operação de montagem é terceirizada. Todos os operadores são funcionários de uma empresa prestadora de serviços, e somente o engenheiro supervisor da linha pertence à empresa.

A empresa B se utiliza de uma forma de Engenharia distribuída. Dentro da estrutura da empresa, todo o desenvolvimento de novos produtos relativo a uma linha é realizado em um centro de excelência. No caso da linha de computadores pessoais, o produto montado no Brasil, o desenvolvimento é feito em um centro localizado na França (outras linhas possuem centros de excelência em outras localidades).

Cada linha de produtos possui, alem do centro de excelência, um laboratório de pesquisa básica. A pesquisa aplicada e o desenvolvimento podem ser realizados dentro do centro de excelência ou terceirizados (nesse caso coordenados pelo centro). Para direcionar os seus esforços, o centro de excelência possui uma atividade de Marketing, que consulta as diversas unidades locais e define os produtos a serem desenvolvidos.

A Engenharia local de cada unidade realiza basicamente a definição de quais produtos dentro do leque disponível serão lançados no seu mercado e o desenvolvimento e adaptação dos processos de manufatura, com a introdução e adaptação dos novos 
produtos para a unidade local, inclusive com acompanhando ciclo de vida do produto. Em geral novos produtos são introduzidos a cada 6 meses.

O lançamento de um novo produto segue a seguinte seqüência: O centro de excelência, através do seu departamento de marketing, entra em contato com as diversas unidades locais, e desenvolve plataformas básicas. Essas plataformas básicas são disponibilizadas para todas as unidades, sob a responsabilidade do centro de excelência.

O departamento de marketing local, de cada unidade, configura o produto que pretende colocar em seu mercado partir das plataformas disponíveis. A definição inicial do tipo de produto a ser desenvolvido, é feita em contato com a Engenharia local, para respeitar as limitações técnicas da sua linha de produção.

Após essa definição, a Engenharia começa o estudo da estrutura do produto escolhido. Nesse momento, de acordo com a sua complexidade ou grau de inovação, o contato com o centro de excelência é maior ou menor. No caso de produtos muito complexos ou inovadores pode ser justificável inclusive a viagem de engenheiros da unidade local para o centro de desenvolvimento.

O produto e o processo produtivo, incluindo a linha de montagem, os sistemas de teste e treinamento de operadores, são desenvolvidos e adaptados para as condições locais, e o produto é então lançado. As unidades locais recebem periodicamente visitas de acompanhamento e auditoria dos engenheiros do centro de excelência.

A comunicação com o centro é mais intensa (até mais de uma vez por dia) durante as fases de lançamento de novos produtos, utilizando principalmente correio eletrônico e telefone. Após essa fase, as comunicações perdem bastante em freqüência, ocorrendo quase que exclusivamente em função de problemas inesperados.

Anualmente a coordenação da linha de produtos promove uma reunião com a participação de todas as unidades. Esse contato permite consultas entre unidades, porém 
isso tem um caráter totalmente informal. Qualquer informação que necessite de um caráter mais formal precisa ser obtida através do centro de excelência. As visitas ao centro de desenvolvimento e à coordenação da linha de produtos têm freqüência anual.

\section{DISCUSSÃO DOS RESULTADOS}

\section{Empresa A}

A empresa A dispõe de laboratórios centralizados de pesquisa e desenvolvimento para cada área de negócios, mas para a Engenharia, a empresa adotou um arranjo fortemente descentralizado. Não existe um departamento de Engenharia central que realize projetos. O órgão central existente desempenha mais uma função de coordenação técnica, comercial e de disseminação de informações. Todas as atividades de Engenharia são realizadas pelas unidades locais, que precisam realizar todas as funções do elenco de atividades proposto na figura 2. A empresa produz sob encomenda, começando os trabalhos de projeto após os fechamento do pedido.

A estrutura de Engenharia descentralizada da empresa A é suportada por uma estrutura administrativa igualmente descentralizada. O conceito de independência local é forte porque é seguido de uma forma coerente por toda a unidade. Administrativamente cada uma dela é vista como um centro de custo independente, que deve gerar lucro pelas suas próprias atividades.

As atividades da Engenharia local compreendem todas as descritas no esquema a seguir: 


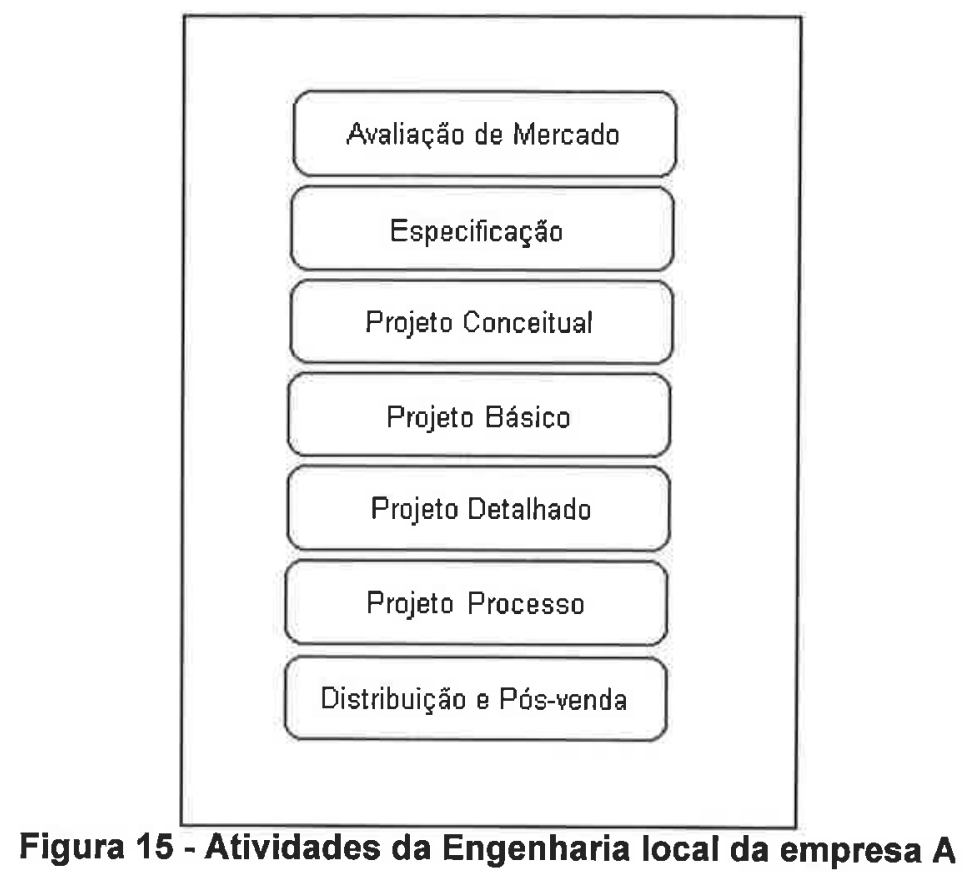

Existe um contato e troca de informações intenso entre as unidades locais de Engenharia. É comum que uma unidade local de Engenharia utilize conhecimentos de outras unidades, existindo troca de informações de interesse comum. O grau de interdependência entre unidades é grande, e em projetos como no exemplo dado no estudo de caso, uma unidade local depende do trabalho das outras.

Nesses trabalhos o grau de interdependência varia entre o recíproco, na fase inicial (definição das especificações e projeto conceitual) e nas etapas finais (trabalhos de inspeção, montagem e posta-em-marcha), quando existe dependência simultânea entre as unidades, para a seqüencial, nas fases intermediárias do projeto (trabalhos de adaptação de materiais e processos de fabricação para a unidade brasileira). A mudança no grau de interdependência com o avançar das fases é uma fenômeno esperado, indicado pela literatura (ver Adler, 1992).

Como cada forma de interdependência contém as outras mais simples, podemos classificar o tipo como o mais complexo entre os dois, nesse caso o recíproco. A natureza da comunicação entre unidades é orgânico. Esquematicamente o arranjo organizacional da Engenharia pode ser representado como: 


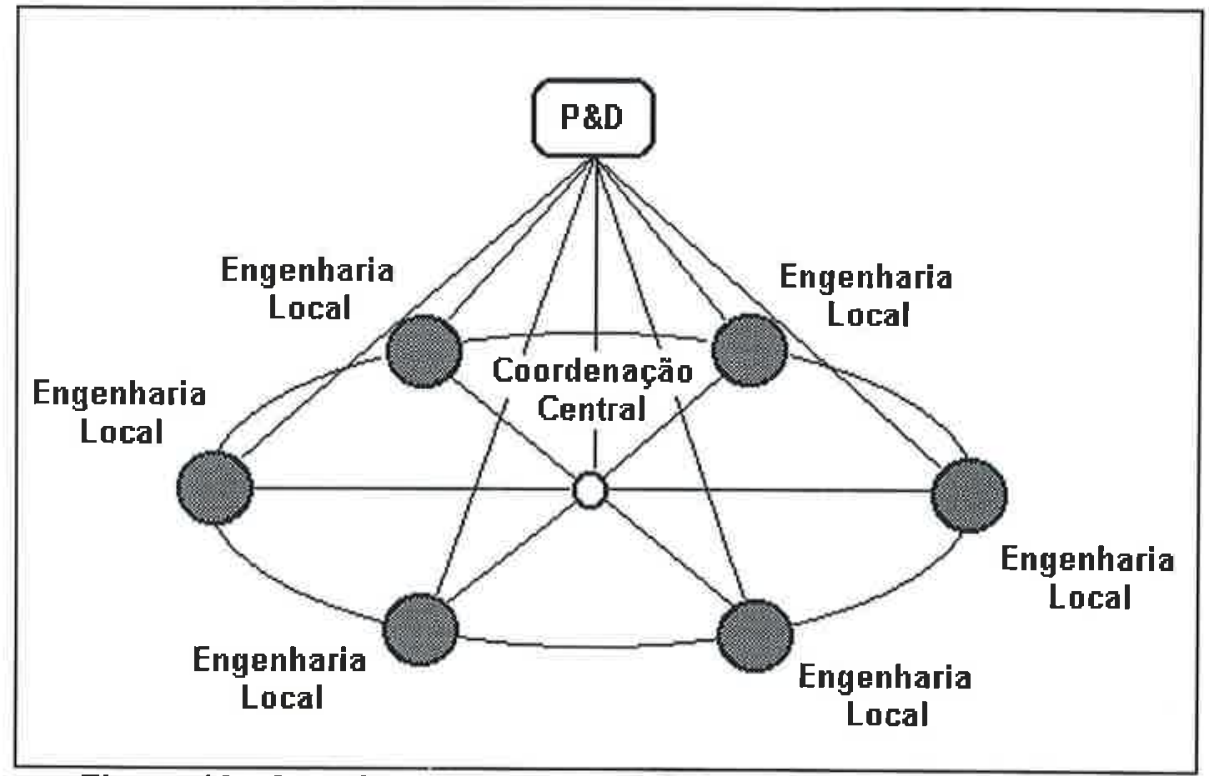

Figura 16 - Arranjo organizacional da Engenharia da empresa A

\section{Empresa B}

A empresa B dispõe também de laboratórios de Pesquisa e Desenvolvimento centralizados, divididos por linhas de produto. Porém, de forma diferente da empresa A, possui um centro de Engenharia centralizado ( o centro de excelência) para cada linha de produtos. Esse centro trabalha desenvolvendo plataformas de produtos, que serão utilizadas pelas unidades locais de Engenharia ${ }^{7}$. Para orientar esses desenvolvimentos, o centro possui uma função de Marketing com preocupação de médio e longo prazo, que consulta constantemente as funções de marketing locais, procurando antever as necessidades de cada mercado.

As Engenharias locais trabalham a partir das plataformas, configurando-as para atender as suas necessidades específicas, e adaptando as suas linhas de produção para cada produto específico. As atividades são divididas da seguinte forma:

\footnotetext{
${ }^{7}$ Wheelwright e Clark, (1992, p.92-97) definem 5 tipos de projetos: (a) Derivativo - desenvolvido a partir de pequenas modificações em um projeto básico, (b) Plataforma - Projeto básico desenvolvido com o objetivo de gerar outros, (c) Radical - Projeto que envolve mudanças significativas de processo ou um produto totalmente novo. Os outros dois tipos são: projetos em parceira e projetos de P\&D.
} 


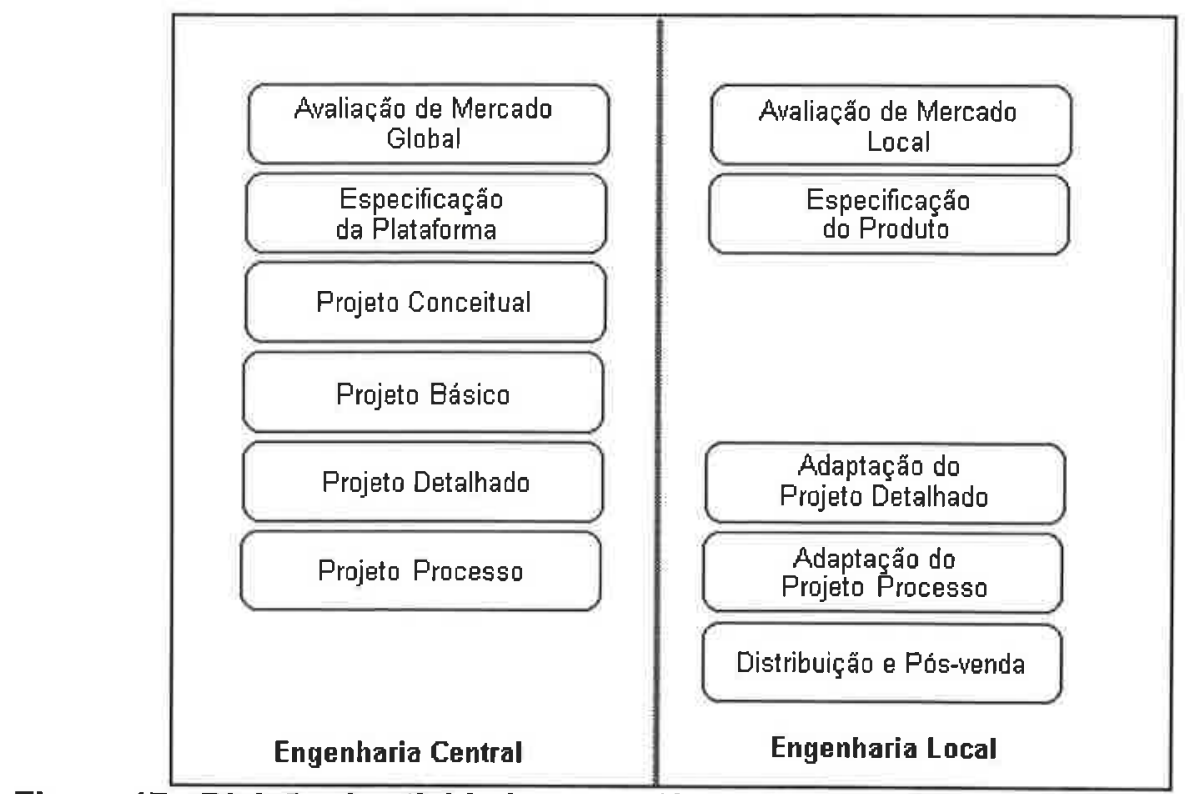

Figura 17 - Divisão de atividades entre Engenharia local e central na empresa $B$

O grau de interdependência entre as unidades locais de Engenharia é baixo. As unidades locais trabalham tipicamente na forma de interdependência por associação, de forma paralela, sem interferência lateral, dependendo quase exclusivamente do centro de Engenharia. A natureza da comunicação entre unidades é mecanicista. Esquematicamente o arranjo da Engenharia é representado por:

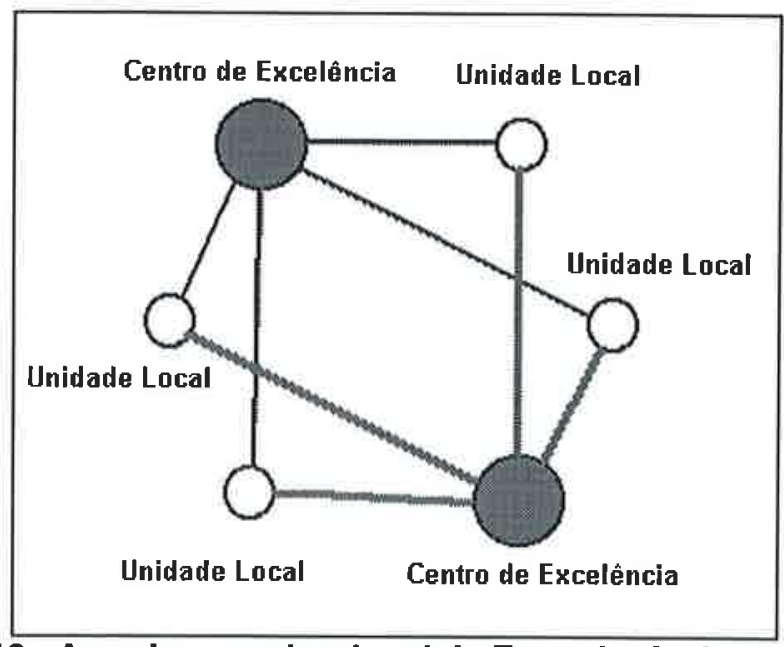

Figura 18 - Arranjo organizacional da Engenharia da empresa B 


\section{ANÁLISE CRÍTICA DOS RESULTADOS E CONCLUSÕES}

As empresas A e B atuam em diferentes setores industriais, com produtos diferentes, atendendo a mercados diferentes. Fazendo a comparação entre as duas empresas, usando a matriz da figura 8 , podemos observar que:

A empresa A tem um produto de alto grau de complexidade de estrutura interna, compostos de inúmeras partes, envolvendo inclusive a coordenação com subfornecedores. Possui também uma interface produto/usuário complexa, pois o seu cliente normalmente é um consórcio de compradores e usuários, que vão avaliar o produto utilizando um grande número de critérios de aceitação. Além disso, o seu produto engloba não somente o equipamento em si, mas todo um pacote de serviços associados, como a negociação de financiamentos, o projeto, a instalação, montagem e a posta-em-marcha. Isso aumenta o número de critérios subjetivos de avaliação por parte do cliente.

Por outro lado o produto da empresa B, embora utilize tecnologia sofisticada, tem número de componentes pequeno e montagem simples (é possível a um amador por exemplo montar um computador pessoal similar ao fabricado pela empresa $B$ comprando um kit de peças). A interface produto/usuário também é mais simples, pois embora a empresa atenda o mercado corporativo, mais exigente do que o de varejo, e ofereça soluções integradas, com o fornecimento de alguns serviços associados, o número de critérios de avaliação utilizados pelos clientes é mais baixo, pelo produto ser mais simples e de desempenho conhecido.

Podemos localizar as empresas dentro do esquema proposto da seguinte forma: 


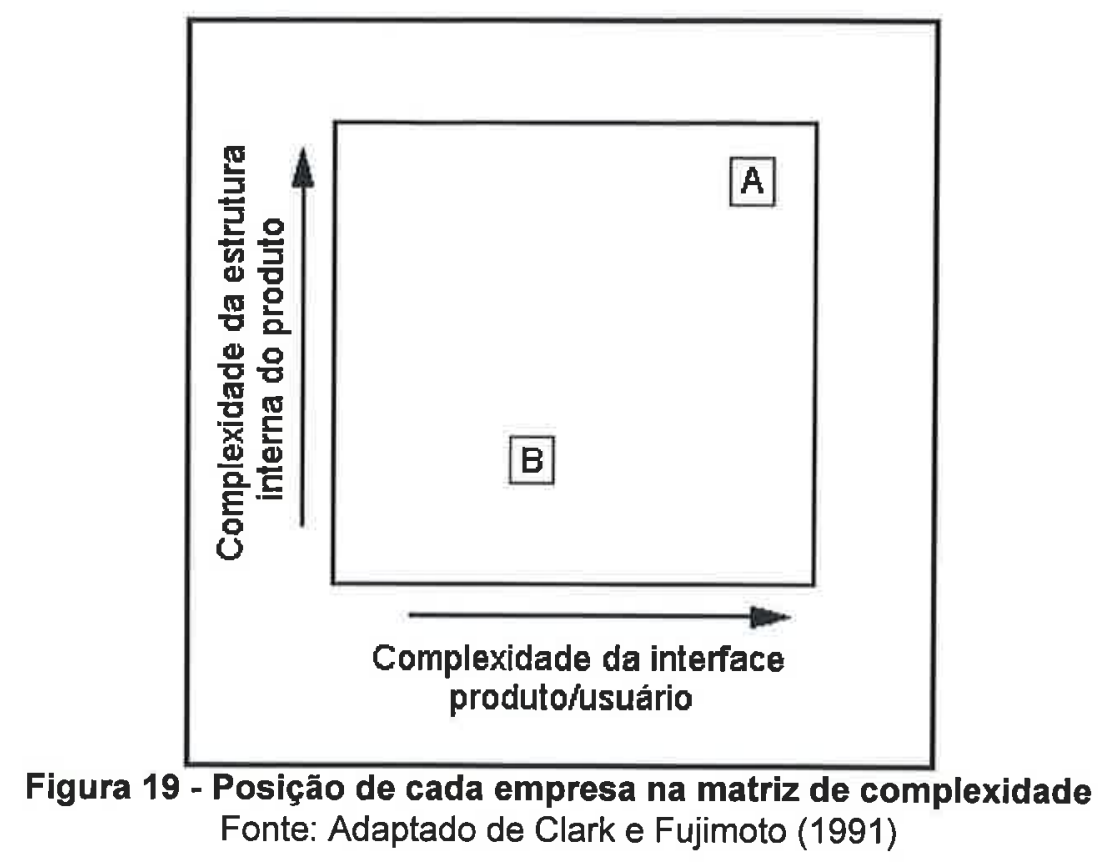

Parece-nos que principalmente devido à complexidade do seu ambiente, isto é, da interface produto/usuário, a empresa $\mathrm{A}$ tenha optado por possuir departamentos de Engenharia descentralizados. A necessidade de atender a diversos clientes, com diferentes demandas e com rapidez exige que a empresa possua uma Engenharia capaz de responder a essas demandas. Por outro lado, a empresa B, por possuir uma interface produto/usuário mais simples, pode prescindir de uma Engenharia local mais poderosa, podendo centralizar as atividades de Engenharia mais complexas no seu centro de excelência, e deixando tarefas mais simples para as unidades de Engenharia locais.

A empresa A utiliza todas as formas de coordenação e controle para os seus serviços de Engenharia. Além das formas mais comuns, regras, planos e procedimentos, hierarquia e planejamento conjunto, faz uso intenso de sistemas de informação verticais e relações laterais. Está desenvolvendo um sistema informatizado específico para a troca de informações técnicas, além de um programa de padronização e normalização dos projetos. Estimula também, através de reuniões freqüentes (pelo menos quatro vezes por ano), o contato direto entre os gerentes de Engenharia locais, de modo a promover e facilitar o contato e intercâmbio direto entre as unidades locais. 
A empresa B, por outro lado, tem um sistema de coordenação e controle mais simplificado. Utiliza as formas comuns de coordenação e controle e também faz uso de um sistema de informações vertical, porém de uso geral, sendo utilizado para todas as outras funções, como administração e vendas, não sendo desenvolvido especificamente para a Engenharia, como na empresa A. Não existe também um esforço dirigido no sentido de promover o contato lateral entre as unidades. Anualmente é realizada uma reunião entre as diversas unidades, mas as trocas de informações laterais são consideradas informais. Quando existe necessidade de qualquer informação "oficial", ela deve ser conseguida através do centro de excelência.

A empresa A tem características que a aproximam mais do tipo orgânico do que a empresa B. Conforme já mencionamos, entre as características do tipo orgânico estão: Estrutura em rede para controle, autoridade e comunicação, o conhecimento específico sobre uma tarefa pode estar localizado em qualquer parte da organização e a comunicação lateral é predominante sobre a vertical. Por outro lado, as características do tipo mecanicista correspondentes são Estrutura hierárquica de controle, autoridade e comunicação, concentração de conhecimento no topo da hierarquia e tendência à interação vertical entre os membros (Burns e Stalker, 1977).

Portanto o tipo de comunicação da empresa A se aproxima do padrão orgânico, enquanto o tipo de comunicação da empresa B do mecanicista. Isso sugere que devido à necessidade de grande capacidade de processamento de informações, a empresa A estimule grande contato e informalidade entre os seus departamentos de Engenharia, enquanto que a empresa $B$, por não ter necessidade tão grande, tem uma comunicação mais formal.

A comparação entre as duas empresas é resumida no seguinte quadro: 


\begin{tabular}{|c|c|c|}
\hline \multicolumn{3}{|c|}{ Características das empresas } \\
\hline & Empresa A & Empresa B \\
\hline $\begin{array}{l}\text { Número de unidades de } \\
\text { Engenharia locais }\end{array}$ & Múltiplo & Múltiplo \\
\hline Tarefa da Engenharia local & Complexa & Simples \\
\hline Ambiente & $\begin{array}{l}\text { Interface com o usuário mais } \\
\text { complexa }\end{array}$ & $\begin{array}{c}\text { Interface com o usuário mais } \\
\text { simples }\end{array}$ \\
\hline $\begin{array}{l}\text { Grau de interdependência } \\
\text { entre unidades de } \\
\text { Engenharia local }\end{array}$ & Complexa (Reciproca) & Simples (Associação) \\
\hline \multicolumn{3}{|c|}{ Observação da Pesquisa } \\
\hline Natureza da comunicação & Orgânico & Mecanicista \\
\hline $\begin{array}{l}\text { Tipo de mecanismo de } \\
\text { coordenação e controle }\end{array}$ & Complexo & Simples \\
\hline
\end{tabular}

Tabela 6 - Comparação entre as duas empresas pesquisadas

Este resultado confirma nossa proposição de pesquisa. Constatamos nos dois estudos de caso que o aumento de complexidade da tarefa e do grau de interdependência aumenta a complexidade dos mecanismos de coordenação e controle e aproxima a natureza da comunicação entre unidades do modo orgânico.

Observamos que uma empresa bem sucedida busca, através da configuração de seu arranjo organizacional, o equilíbrio entre a sua necessidade e sua capacidade de processamento de informações. Um maior nível de exigência leva a um arranjo com aspectos mais complexo, assim como a redução dessas exigências reduz a complexidade do arranjo organizacional.

É importante lembrar que as duas empresas estudadas são bem-sucedidas (pelo menos até o presente momento) e gozam de prestígio e reputação no mercado. A empresa B, ao optar por possuir um padrão de comunicação mecanicista entende que dentro do seu 
arranjo organizacional esse tipo de comunicação é o mais adequado, sendo suficiente para suas necessidades atuais e incorrendo em custos que ela julga serem razoáveis.

A empresa A, ao optar por um arranjo mais complexo, precisou adaptar seus sistemas de controle e coordenação para isso, pagando os custos relativos a escolha. Porém essa escolha foi feita segundo o que acredita ser mais adequado para suas características, dentro de sua estratégia de produto e mercado e características da sua interface produto/usuário, conforme já discutimos no início desta seção.

Em resumo, podemos dizer que a necessidade de equilíbrio entre necessidade e capacidade de processamento de informações recai diretamente sobre a escolha e projeto do arranjo organizacional. Conforme vimos, a escolha entre centralização e descentralização funcional dos departamentos de Engenharia interfere na complexidade da tarefa das unidades locais, e da mesma forma sobre o grau de interdependência sobre elas. Isso vai conduzir à necessidade de uma maior ou menor investimento em sistemas de informação, no incentivo ao contato direto entre unidades locais e em diferentes graus de formalidade na comunicação.

Investimentos em sistemas de informação para a Engenharia devem considerar esses fatores para serem corretamente planejados. Sistemas superdimensionados podem significar custos desnecessários para a organização, assim como por outro lado, sistemas com pequena capacidade vão exigir a criação de outros mecanismos para aumento de capacidade, que podem não ser adequados para o arranjo organizacional escolhido, produzindo inconsistências internas à organização.

A escolha entre um arranjo centralizado ou descentralizado parece também estar condicionada à complexidade da interface produto/usuário. Quanto mais complexa essa interface, mais complexas necessitam ser as tarefas da unidade de Engenharia local, o que exige capacidade técnica distribuída entre as unidades locais, ou em outras palavras, maior descentralização. Isso favorece a dispersão do conhecimento entre as unidades, exigindo uma interdependência entre elas mais complexa. Portanto quanto maior a 
complexidade da interface produto/usuário, maior a tendência à descentralização das atividades de Engenharia.

O conceito de equilíbrio necessidade/capacidade parece ser uma poderosa ferramenta de análise e projeto de arranjos organizacionais. Nossa conclusão final é que existe forte evidência que empresas bem sucedidas possuem arranjos organizacionais que fornecem capacidade de transmissão e processamento de informações adequada ao tipo de tarefa e ambiente em que atuam, e que a descentralização das atividades de Engenharia é fortemente influenciada pelo grau de exigência e complexidade da relação com o cliente.

\section{COMENTÁRIOS FINAIS E DIREÇÕES PARA PESQUISA FUTURA}

Dado o crescente movimento de internacionalização das empresas por aquisições e fusões no Brasil, o estudo da Engenharia parece cada vez mais atual. Mesmo com as iniciativas de centralização das atividades de pesquisa e desenvolvimento realizadas por diversas empresas, sempre teremos a existência de departamentos de Engenharia em cada país, pela necessidade de adaptação dos produtos e processos à realidade de cada local. Dessa forma, entender a atuação da Engenharia significa entender parte da forma como as cmpresas atuam em nosso país.

A nosso ver portanto, estudos sobre a Engenharia, tanto em empresas nacionais como nas multinacionais são oportunos e necessários para acompanhar a evolução e perspectivas da indústria brasileira. Esse acompanhamento permite não só uma visão da indústria, mas também discussões sobre o mercado de trabalho para os engenheiros, assim como o perfil profissional requisitado pelas empresas. Por exemplo, conforme observamos, mesmo em arranjos que façam a opção centralizada ou distribuída, sempre será necessária a manutenção das Engenharias locais, ainda que com tarefas 
simplificadas. Porém nesse caso o número de profissionais de Engenharia necessários nas unidades locais é menor do que no caso de empresas com arranjo descentralizado. A opção entre os tipos de arranjo organizacional define a quantidade de profissionais técnicos nas unidades de Engenharia locais.

Quanto à questão da qualificação profissional, parece-nos também que a opção entre um arranjo centralizado, distribuído e descentralizado modifica o perfil demandado. Partindo de nossa conclusão que a interface produto/usuário deve ser um dos critérios considerados para a opção de arranjo organizacional, interfaces mais complexas exigiriam ou um maior número de profissionais especializados ou profissionais mais ecléticos, capazes de fazer frente às variadas demandas do mercado. Como temos observado uma forte tendência à redução dos quadros de pessoal, a segunda alternativa parece mais provável. Isso significa a necessidade da formação de engenheiros mais versáteis e menos focalizados apenas nas suas especialidades técnicas.

Corre paralela à discussão realizada neste trabalho também a preocupação quanto à capacitação tecnológica nacional com as fusões e aquisições de empresas brasileiras por multinacionais. Diversas empresas têm optado por arranjos centralizados de P\&D e Engenharia, e com isso têm transferido atividades de desenvolvimento para outros países. Se mesmo anteriormente a esses fatos a capacitação tecnológica das empresas brasileiras era colocada em questão (ver por exemplo Coutinho, 1996), parece-nos que os movimentos recentes podem contribuir ainda mais para a fragilização dessa capacidade tecnológica.

Retornando ao pensamento inicial dessa seção, entendemos que o tema Engenharia necessita um maior volume de estudos, que discutam os diversos aspectos relacionados com o tema. Além do aspecto organizacional, foco desse estudo, os assuntos mencionados anteriormente, como mercado de trabalho e perfil profissional dos engenheiros em funções técnicas e capacitação tecnológica das unidades locais, bem como questões relativas à transferência de tecnologia carecem de estudos específicos. 
Este estudo contribuiu parcialmente na reposta à pergunta inicial: "Como as empresas com múltiplos departamentos de Engenharia estão se estruturando para competir no mercado globalizado?" Analisando a questão da centralização e descentralização, concluímos que uma condição importante para uma estrutura bem sucedida é a escolha de arranjos organizacionais que equilibrem a capacidade de transmissão e processamento de informações inerente à suas características com a necessidade de processamento de informações oriunda das características da tarefa, ambiente e da forma de interdependência escolhida.

Concluímos também que a opção entre a centralização e a descentralização das atividades de Engenharia é fortemente influenciada pelo grau de complexidade da relação com o cliente, ou como denominamos ao longo do estudo, da interface produto/usuário. Parece-nos que empresas bem sucedidas conseguem manter a necessária capacitação técnica em suas unidades locais de forma a atender satisfatoriamente o seu mercado. Dessa forma, a estratégia corporativa deve considerar o tipo de produto e o seu mercado para definir seu arranjo organizacional.

Algumas questões específicas ficam abertas neste trabalho. A primeira delas é quando ao modelo de equilíbrio necessidade/capacidade de processamento de informações, ilustrado na figura 13. Concluímos que as variáveis apresentadas no modelo de fato influem no estudo da organização como sistema de processamento de informações. Porém não discutimos a possível existência de outras variáveis que pudessem interferir nesse equilíbrio.

Outra questão interessante é relativa aos critérios utilizados pelas empresas que optam por arranjos centralizados ou distribuídos para a escolha do ponto de corte entre as tarefas realizadas na Engenharia central e nas unidades locais. Conforme já argumentamos, é nossa opinião que sempre devam existir os departamentos de Engenharia locais, mas este estudo, embora reconhecendo a importância desse aspecto, não procurou discutir os critérios que devem ser utilizados para a definição do conjunto 
de atividades das Engenharias locais. Assim como já comentamos, esse ponto de corte influencia a quantidade e tipo de profissional que a empresa vai necessitar.

Fizemos ao longo de nossa argumentação a simplificação do ambiente competitivo da empresa, usando apenas a variável relacionada ao cliente ou usuário, que avalia a complexidade da relação e da forma de avaliação utilizada por ele. Outros estudos que estudem a influência das outras variáveis do ambiente competitivo, especialmente concorrentes e fornecedores, e principalmente a sua possível influência na opção por centralização e descentralização da Engenharia seriam necessários.

Outro aspecto que foi evitado neste estudo é a medição absoluta da necessidade de processamento de informações. Um instrumento capaz de, a partir da análise da tarefa, ambiente e interdependência, quantificar essa necessidade seria uma ferramenta de análise organizacional poderosa, que permitiria tanto a verificação quanto o projeto de arranjos organizacionais.

Assim, concluindo, é nossa opinião que o próprio modelo de sistema de processamento de informações utilizado, que contrapõe a complexidade da tarefa e seu ambiente e o tipo de interdependência entre unidades com a natureza da unidade e a forma de coordenação e controle também pode ser mais profundamente estudado. Não encontramos na literatura estudos que aprofundassem esses conceitos ou, conforme já comentamos, que procurassem verificar a existência de outras variáveis de influência. E de um ponto de vista mais genérico, entendemos que mais pesquisas sobre a relação entre arranjos organizacionais e fluxo de informações, não somente do ponto de vista da Engenharia, são necessárias. 


\section{BIBLIOGRAFIA}

Adler, Paul, S. - Managing DFM: learning to coordinate product and process design. In: Susman, Gerald I. ed. - Integrating design and manufacturing for competitive advantage. New York, Oxford University Press, 1992.

Allen, Thomas J. - Managing the flow of technology. Massachusetts, MIT Press, 1977.

Allen, Thomas J., Lee; Denis M.; Tushman, Michael - R\&D performance as a function of internal communication, project management, and the nature of the work. IEEE Transactions on Engineering Management, v.27, n 1, Feb 1980.

Almeida, Henrique S. - Estudo do vínculo tecnológico entre: Pesquisa, Engenharia, Fabricação e Consumo. São Paulo, Tese (Doutorado), Escola Politécnica, Universidade de São Paulo, 1981, 163 p.

Barbieri, José C. - Produção e Transferência de Tecnologia. São Paulo, Ática, 1990, $181 \mathrm{p}$.

Barczak, Gloria; Wilemon, D. - Communications patterns of new product team leaders. IEEE Transactions on Engineering Management, v.38, p. 101-9, may 1991.

Bartlett, Cristopher A .; Ghoshal, Sumantra - Gerenciando empresas no exterior. São Paulo, Makron, 1992, 360 p.

Burns, Tom; Stalker, G.M. - The management of innovation. London, Tavistock, 1977.

Carter, D.E.; Baker, B.S. - Concurrent Engineering, the product development enviroment for the 1990s. Massachusetts, Addison-Wesley, 1992.

Chiesa, Vittorio - Human resource management issues in global R\&D organizations: A case study. Journal of engineering and technology management, v.13, p.189-202, 1996.

Clark, K.B.; Fujimoto, T. - Product development performance. Boston, Harvard Business School Press, 1991.

Clausing, Don - Total Quality Development. New York, ASME Press, 1994, 506p.

Coutinho, Luciano - Globalização e capacitação tecnológica nos países de industrialização tardia: lições para o Brasil. Gestão e Produção, v.3, n.1, p.49-69, 1996. 
Elmes, Michael; Wilemon, David - Determinants of cross-functional cooperation in technology-based organizations. Engineering management review, Spring 1992.

Eureka, W. E. e Ryan, N. E. - QFD: Perspectivas gerenciais do desdobramento da função qualidade. Rio de Janeiro, Qualitymark, 1993.

Fleury, Afonso C.C. - A questão da Tecnologia e a Organização da Engenharia na empresa industrial brasileira. São Paulo, Tese (Livre docência), Escola Politécnica, Universidade de São Paulo, 1983, 151 p.

Fleury, Afonso ; Plonski, Guilherme A. - Desafios para a Engenharia nas empresas industriais no novo contexto competitivo. Inova, Gestão \& Tecnologia, São Paulo, NPGCT-USP, Jan/Abr 1994.

Fotta, Michael E.; Daley, Ray A. - Improving interpersonal communications on multifunctional teams. In: Parsaei, Hamid, R.; Sullivan, Willian G. ed. - Concurrent engineering, contemporary issues and modern design tools, London, Chapman \& Hall, 1993.

Galbraith, Jay R. - Designing complex organizations, Reading, Addison-Wesley, 1973.

Galbraith, Jay R.; Lawler, Edward E. III. - Organizando para competir no futuro. São Paulo, Makron, 1995, 287 p.

Glaser, Barney G.; Strauss, Anselm L. - The Discovery of grounded theory, New York, Aldine de Gruyter, 1967.

Hayes, R.H.; Wheelwright, S.C. - Restoring our competitive edge. Competing through manufacturing. New York, John Wiley, 1984.

Iansiti, Marco - Technology development and integration: an empirical study of the interaction between applied science and product development. IEEE Transactions on Engineering Management, v.42, n.3, p.259-69, Aug 1995.

Junqueira, G.B. - Da engenharia tradicional à engenharia simultânea no setor industrial brasileiro. - Dissertação (Mestrado), Escola Politécnica, Universidade de São Paulo, São Paulo, 1994.

Kruglianskas, Isak. - Engenharia simultânea: organização e implantação em empresas brasileiras. Revista de Administração, São Paulo, v.28, n. 4, p.104-10, out/dez 1993.

Morelli, Mark M.; Eppinger, Steven D.; Gulati, Rosaline K. - Predicting technical communication in product development organizations. IEEE transactions on engineering management, v.42, n.3, aug, 1995.

Muniz Júnior, Jorge - A utilização da Engenharia Simultânea no aprimoramento contínuo e competitivo das organizações. Estudo de Caso do modelo usado no avião 
EMB 145 da EMBRAER. São Paulo, Dissertação (Mestrado), Escola Politécnica , Universidade de São Paulo, 1995.

O'Connor, Patrick D.T. - The practice of engineering management. Chichester, John Wiley, 1994, 235p.

PMBOK - A guide to the project management body of knowledge (PMBOK). Upper Darby, Project Management Institute, exposure draft, 1994.

Porter, Michael - Estratégia Competitiva. São Paulo, Campus, 1986, 362 p.

Pugh, Stuart - Total Design. Wokingham, Addison-Wesley, 1990, 277 p.

Rosenblatt, A.; Watson, G.F. - Concurrent engineering, special report. IEEE Spectrum, jul, 1991, p.51.

Rosenthal, Stephen R. - Effective Product Design and Development. Homewood, Business One Irwin, 1992.

Rosenthal, Stephen R.; Takikonda, Mohan V. - Competitive advantage through design tools and practices. In: Susman, Gerald I. ed. - Integrating design and manufacturing for competitive advantage. New York, Oxford University Press, 1992.

Santos, José A .- Desenvolvendo produtos competitivos. Exemplo de um modelo integrando a metodologia "Função Desdobramento da Qualidade (QFD)". São Paulo Tese (Doutorado), EAESP/FGV, 1996.

Shina, S.G. - New rules for world-class companies. In: Concurrent engineering, special report. IEEE Spectrum, jul 1991, p. 52.

Slack, Nigel - Vantagem competitiva na manufatura. São Paulo, Atlas, 1993, 198 p.

Susman, Gerald I. ed. - Integrating design and manufacturing for competitive advantage. New York, Oxford University Press, 1992.

Teixeira, Descartes - Pesquisa, desenvolvimento experimental e inovação industrial: Motivações da empresa privada e incentivos do setor público. In: Marcovitch, Jacques ed. - Administração em Ciência e Tecnologia. São Paulo, Edgard Blucher, $1983,503 \mathrm{p}$.

Thompson, James D. - Organizations in action. New York, McGraw-Hill, 1967.

Tushman, Michael L.; Nadler, David A. - Information processing as an integrating concept in organizational design. Academy of management review, July 1978, p. 61324.

Vasconcellos, Eduardo - Centralização x descentralização: uma aplicação para laboratórios de instituições de pesquisa e desenvolvimento. Revista de Administração LA-USP, v.14 n.2, 1979, p.101-121. 
Vasconcellos, Eduardo; Hemsley, J.R. - Estrutura das Organizações, São Paulo ,Pioneira, 1989.

Vesey, J.T. - The new competitors: they think in terms of "speed to market". IEEE Engineering Management Review, v.19, n.4, 1991.

Wheelwright, Steven C.; Clark, Kim B. - Revolutionizing Product Development, New York, Free Press, 1992, 364 p.

Workman Jr, John P. - Engineering's interactions with marketing groups in an engineering-driven organization. IEEE transactions on engineering management, v.42, n.2, may, 1995.

Yin, Robert K. - Case study research: design and methods. Thousand Oaks, Sage, 1994, 171p. 